\title{
Applicability of Fuzzy TOPSIS Method in Optimal Portfolio Selection and an Application in BIST
}

\author{
Oguzhan Ece $^{1} \&$ Ahmet Serhat Uludag ${ }^{2}$ \\ ${ }^{1}$ Department of Banking and Finance, Faculty of Economics and Administrative Sciences, Erzincan University, \\ Erzincan, Turkey \\ ${ }^{2}$ Department of International Trade and Logistics, Faculty of Economics and Administrative Sciences, Ondokuz \\ Mayis University, Samsun, Turkey \\ Correspondence: Oguzhan Ece, Department of Banking and Finance, Faculty of Economics and Administrative \\ Sciences, Erzincan University, Yalnızbag Campus, Erzincan, Turkey. Tel: 90-446-225-2092-41051. E-mail: \\ oguzece25@gmail.com
}

Received: August 4, 2017

Accepted: August 25, 2017

Online Published: September 5, 2017

doi:10.5539/ijef.v9n10p107

URL: https://doi.org/10.5539/ijef.v9n10p107

\begin{abstract}
General structure of saving-investment cycle and the effectiveness of this structure are included in the most significant issues of the financial system. One of the points of intervention in providing an effective saving-investment cycle is possible through channeling the savings toward optimal investment fields. This study aims at detecting the existence of alternative methods in determining optimal selection combination in the risk and revenue perspective of individual and corporate investors who would like to evaluate their savings in capital markets. For this purpose, the applicability of Fuzzy TOPSIS method, one of the multi-criteria decision making techniques in optimal portfolio selection was researched. The applicability of the stock investment alternatives ranked according to Fuzzy TOPSIS method was examined by comparing them to the optimal selection results determined according to Markowitz, one of the modern portfolio management techniques. In the study where performance indexes were used as assessment criteria the results of both methods were discussed in terms of risk at a certain revenue level and revenue at a certain risk level through Johnson and Sharp Indexes. The results obtained determined that the Fuzzy TOPSIS portfolio alternatives created using Fuzzy TOPSIS method revealed quite positive results in terms of performance, revenue and risk and pointed at applicability of Fuzzy TOPSIS method in optimal portfolio selection as well.
\end{abstract}

Keywords: optimal portfolio selection, fuzzy TOPSIS, markowitz portfolio optimization method

\section{Introduction}

Lexical meaning of investment is "the money invested into an income-generating movable or immovable property" (http://tdkterim.gov.tr/bts/). As can be understood from the definition, to generate income, the deposit should be attached to an asset. Today, increased variety of options that the investors can attach their deposits to helps decrease the risks they face. Securities, which is one of these options, are now among the main investment instruments through which investors can use their deposits, obtain income, and distribute the risk by diversification. In this context, obtaining the desired return is closely related to the determination of the securities that will provide the highest return, or to the creation of an optimal portfolio that includes these securities.

The optimal portfolio is the choice of the security component that will provide the highest return at a certain risk level that the investor can bear. The portfolio selection that constitutes the decision phase of how an investor will distribute his or her wealth in a securities basket is a technical process that constitutes the third stage of portfolio management. The only determinant of the process is based on return and risk comparisons. Portfolio selection, which has become one of the most important area of study in modern finance, is referred to in the literature as Modern Portfolio theory, which is based on the pioneering work of Markowitz and Sharpe (Solimanpur et al., 2015; Ceylan \& Korkmaz, 1998). The basic assumptions of the theory can be summarized as follows (Konuralp, 2005; Yoruk, 2000):

a) It is based on maximizing utility. 
b) Hedging is based on diversification.

c) Expected return and risk are accepted as the main determinants of investor decisions.

d) Investors' risk and return expectations are homogeneous and based on the principle of maximization of the return at a certain risk level.

e) Efficient market conditions apply.

f) Investors have the identical time horizon.

Optimal portfolio selection in modern portfolio management, in which the relationship between the securities becomes prominent in terms of hedging, is mathematically calculated by quadratic programming and is called "effective portfolio". Effective portfolios represent securities that have the highest return at the same risk level or that have the lowest risk at the same return level. The curve showing the effective portfolios at different risk and return levels is defined as the "Effective Boundary" and each security component along that boundary represents the optimal investment component for the investor (Karan, 2011).

Considering everything explained up to here, it is understood that to form an optimal portfolio and/or to select the securities to form an optimal portfolio is a decision process that is shaped primarily by risk and expected return. Cognitively, decision is defined in the Turkish Dictionary of the Turkish Language Society as "the definite judgment reached by thinking about a job or a problem" (http://tdkterim.gov.tr/bts/); whereas in terms of business management, decision is defined as "the choice the manager or any other person makes in any subject", (Kocel, 2005). In essence, the gist of decision making is the pursuit of; "choosing the most suitable or the most appropriate one among the choices after thinking thoroughly on a subject"(Ulgen \& Mirze, 2010). Similar to all decision-making processes, there are many alternatives for investors who are also decision makers in the selection of optimal portfolios, and there are quite a number of decision criteria that can be used to evaluate these alternatives. No doubt, within the scope of this study, what is meant by alternatives is the securities, and what is meant by decision criteria is the financial ratios.

Particularly in the field of business management, techniques called multi-criteria decision making methods are frequently used by researchers for solution, when there are a large number of decision criteria and also problems about decision making that require consideration of a large number of alternatives. Some of these techniques only allow the use of the quantitative data whereas some allow the use of both qualitative and quantitative data. Among these techniques TOPSIS, which is one of the traditional multi-criteria decision making methods, focuses on identifying and choosing the alternative that is farthest from the negative ideal solution and closest to the positive ideal solution (Deng et al., 2000); it is a ranking methodology developed by Hwang and Yoon in 1981 (Hsu et al., 2015); and it comprises 6 steps, which are: calculating the normalized decision matrix, calculating the weighted normalized decision matrix, determining the positive and negative ideal solutions, calculating the distribution measures, calculating the proximity to the ideal solution, and the decision criteria should be measurable and comparable (Chen \& Hwang, 1992).

Traditional multi-criteria decision making techniques, which also include TOPSIS, can be inadequate for the types of problems encountered in real life. While this inadequacy can be due to the use of linguistic expressions by those who are at the position of decision making in the evaluation of alternatives or decision points, it can also be due to the classical logic based resolution algorithm of traditional multi-criteria decision making techniques. To eliminate these deficiencies, when evaluating the decision points based on the decision criteria, in addition to use linguistic expressions such as "very poor", "poor", "medium poor", "fair", medium good", "good" and "very good", the use of fuzzy logic instead of classical logic can provide great convenience to the researchers at the point of resolution. While linguistic expressions are highly advantageous when decision criteria have subjectivity or where past experience of decision makers is important for evaluation, the use of fuzzy logic shows a structure suitable for problems encountered in real life by allowing some relationships that can not be included in the membership function according to classical logic to be included in the solution process (Chen, 2000).

In the Fuzzy Logic Theory developed by Luftu-zade in 1965 (Altas, 1999), contrary to classical logic, a member's membership relation to the relevant set is determined using a scale that includes intermediate values or expressions instead of definitive values or expressions, and the probability of occurrence of fuzzy states can be determined (Vural, 2002). Since the fuzzy logic is more useful than classical logic and the expertise, past experience and future expectations of decision makers must be taken into consideration in order to solve the type of problem handled in this study, Fuzzy TOPSIS method, which includes the superior aspects of fuzzy logic and traditional TOPSIS method, is used. 
Fuzzy TOPSIS method has been used to solve many different problems in the field of business management. In this context, before explaining the algorithm of the method, summary of some of the studies in which Fuzzy TOPSIS was used is provided in Table 1.

Table 1. Summary information on some of the studies in which fuzzy TOPSIS method was used

\begin{tabular}{|c|c|c|}
\hline Author(s) & Year & Topic \\
\hline Chen & 2000 & Selection of system analysis engineer \\
\hline Chen & 2001 & Selection of location for distribution center \\
\hline Tsao & 2003 & Assessment of equity investments \\
\hline Bottani and Rizzi & 2006 & Third party logistics service provider choice \\
\hline Chen et al. & 2006 & Supplier evaluation and selection \\
\hline Yong & 2006 & Site selection \\
\hline Ecer & 2006 & Sales staff assessment \\
\hline Dundar et al. & 2007 & Evaluation of web sites of virtual stores \\
\hline${ }^{* *}$ Ecer & 2007 & Choosing a store location \\
\hline Ecer & 2007 & Sales staff assessment and selection \\
\hline Eleren and Ersoy & 2007 & Evaluation of marble block cutting methods \\
\hline Kahraman et al. & 2007 & Logistics information technology \\
\hline Ozdemir ve Secme & 2009 & Strategic supplier choice \\
\hline Mahdi and Hossein & 2008 & Project and contractor selection \\
\hline Onut and Soner & 2008 & Location selection \\
\hline Ozturk et al. & 2008 & Choosing a transportation company \\
\hline Salehi and Moghaddam & 2008 & Project evaluation and selection \\
\hline Ecer et al. & 2009 & Optimal portfolio selection \\
\hline Kucuk and Ecer & 2009 & Supplier choice \\
\hline Gokdalay and Evren & 2009 & Airport performance evaluation \\
\hline Shahanaghi and Yazdian & 2009 & Supplier choice \\
\hline Sun and Lin & 2009 & Evaluation of Web Based Shopping Sites \\
\hline Bagheri and Tarokh & 2010 & Supplier choice \\
\hline Tirmikcioglu and Cinar & 2010 & Site selection \\
\hline Erginel et al. & 2010 & GSM Sector \\
\hline Tan et al. & 2010 & Construction project selection \\
\hline Baskaya and Ozturk & 2011 & Sales staff selection \\
\hline Eraslan and Tansel & 2011 & Investment region selection \\
\hline Eleren and Yilmaz & 2011 & Selection of supplier for textile firm \\
\hline Erkayman et al. & 2011 & Logistics center location selection \\
\hline Madi and Tap & 2011 & Investment boards choice \\
\hline Mangir and Erdogan & 2011 & Analysis of economic performances of countries \\
\hline Ozcakar and Demir & 2011 & Supplier choice \\
\hline Ashrafzadeh et al. & 2012 & Warehouse location selection \\
\hline Awasthi and Chauhan & 2012 & Sustainable city logistics planning \\
\hline Buyukozkan and Cifci & 2012 & Choice of green suppliers \\
\hline Huang and Peng & 2012 & Evaluation of the competitive structure of tourism industry \\
\hline Paksoy et al. & 2012 & Development of organizational strategy in distribution channel management \\
\hline Uysal and Tosun & 2012 & Selection of computerized maintenance management system \\
\hline Yayla et al. & 2012 & Supplier choice \\
\hline Alemi and Akram & 2013 & Evaluation of the leanness of manufacturing systems \\
\hline Sedaghat & 2013 & Productivity development in the banking sector \\
\hline Kahraman et al. & 2013 & Evaluation of investment alternatives in the field of education \\
\hline Maity and Chakraborty & 2013 & Material selection \\
\hline Prascevic and Prascevic & 2013 & Evaluation of optimal alternatives for resource conservation \\
\hline Sari & 2013 & RFID technology selection \\
\hline Vatansever & 2013 & Supplier choice \\
\hline Uludag and Deveci & 2013 & Supplier choice \\
\hline Uludag and Deveci & 2013 & Site Selection \\
\hline Mahdevari et al. & 2014 & Occupational health and safety \\
\hline
\end{tabular}




\begin{tabular}{lll}
\hline Mokhtari et al. & 2014 & Selection of best well control system \\
Yildiz and Yildiz & 2014 & ERP software selection \\
Ardakani et al. & 2015 & Evaluation of service quality \\
Chen and Lu & 2015 & Evaluation of competitive structures of insurance companies \\
Kabra and Ramesh & 2015 & Humanitarian supply chain management \\
Arslan and Yildiz & 2015 & Site selection for sports schools \\
Gul and Uludag & 2016 & Choosing a charismatic leader \\
Akyuz and Kilinc & 2016 & Site selection for a private hospital \\
\hline
\end{tabular}

\section{Mathematical Form of Fuzzy TOPSIS Method}

Although basic stages of the Fuzzy TOPSIS method is the same as the traditional TOPSIS method, its requirement of some special calculations in terms of mathematics makes it slightly operationally complicated. The main stages of the method are presented below in a manner similar to the studies previously shown in Table 1.

Stage 1: In the first phase, the "d" number of decision makers, an ensemble of the group of experts, decision criteria, and identification of alternatives must be defined. In this context, a group of decision makers was formed. " $\mathrm{j}$ " represents decision criteria, " $\mathrm{i}$ " represents the alternatives; and of 21 decision criteria, 15 alternatives were chosen to be used. According to this, $d=(1,2,3), j=(1,2, \ldots, p)$ and $i=(1,2, \ldots, q)$.

Stage 2: In the second stage, the linguistic variables necessary for the weighting of the criteria and for the evaluation of the alternatives according to the criteria should be determined. The linguistic variables to be used in this context and their corresponding triangular fuzzy numbers are determined and shown in Table 2.

Table 2. Linguistic variables and corresponding triangular fuzzy numbers

\begin{tabular}{|c|c|c|c|}
\hline \multicolumn{2}{|c|}{ Weighting of the Criteria } & \multicolumn{2}{|c|}{ Ratings of Alternatives } \\
\hline Variable & Triangle Fuzzy Number & Variable & Triangle Fuzzy Number \\
\hline Very Low (VL) & $(0,0,0.1)$ & Very Poor (VP) & $(0,0,1)$ \\
\hline Low (L) & $(0,0.1,0.3)$ & Poor $(\mathrm{P})$ & $(0,1,3)$ \\
\hline Medium Low (ML) & $(0.1,0.3,0.5)$ & Medium Poor (MP) & $(1,3,5)$ \\
\hline Medium(M) & $(0.3,0.5,0.7)$ & Fair $(\mathrm{F})$ & $(3,5,7)$ \\
\hline Medium High (MH) & $(0.5,0.7,0.9)$ & Medium Good (MG) & $(5,7,9)$ \\
\hline $\operatorname{High}(\mathrm{H})$ & $(0.7,0.9,1)$ & Good $(\mathrm{G})$ & $(7,9,10)$ \\
\hline Very High $(\mathrm{VH})$ & $(0.9,1,1)$ & Very Good (VG) & $(9,10,10)$ \\
\hline
\end{tabular}

Sourse: Chen, 2000.

Stage 3: In the third stage expert opinions are collected for the weighting of the criteria and grading the alternatives.

Stage 4: In this stage, the weights of the criteria and the importance ratings of the alternatives according to the criteria are calculated by the mathematical formulas shown in equations (1) and (2) respectively. In the equations, "d" represents the experts, " $\mathrm{i}$ " the alternatives, and " $\mathrm{j}$ " the decision criteria $(d=1,2,3 ; i=1, \ldots, p$ and $j=$ $1, \ldots, q)$.

$$
\begin{aligned}
& \tilde{h}_{j}=\frac{1}{d}\left[\left(\tilde{h}_{j}^{1}\right)+\left(\tilde{h}_{j}^{2}\right)+\left(\tilde{h}_{j}^{3}\right)\right] \\
& \tilde{t}_{i j}=\frac{1}{d}\left[\left(\tilde{t}_{i j}^{1}\right)+\left(\tilde{t}_{i j}^{2}\right)+\left(\tilde{t}_{i j}^{3}\right)\right]
\end{aligned}
$$

Stage 5: In the fifth stage, fuzzy initial decision matrix indicated as " $\widetilde{\mathrm{S}}$ " and fuzzy weight decision matrix indicated as " $\widetilde{\mathrm{H}}$ " are generated.

$$
\begin{gathered}
\tilde{S}=\left[\begin{array}{ccc}
t_{11} & \ldots & t_{1 i} \\
\ldots & \ldots & \ldots \\
t_{j 1} & \ldots & t_{i j}
\end{array}\right](i=1,2, \ldots, p) \text { ve }(j=1,2, \ldots, q) \\
\widetilde{H}=\left[\tilde{h}_{1}, \tilde{h}_{2}, \ldots, \tilde{h}_{j}\right] \quad(j=1,2, \ldots, q)
\end{gathered}
$$

Stage 6: In the sixth stage, a normalized decision matrix, represented by equation (5), is generated. Here, $t_{i j}=\left(x_{i j}, y_{i j}, z_{i j}\right)$ is a triangular fuzzy number and " $\mathrm{F}$ " represents a benefit, "M" represents a cost: 


$$
\begin{gathered}
G=\left[\tilde{g}_{i j}\right]_{p x q} \quad(i=1,2, \ldots, p) \text { ve }(j=1,2, \ldots, q) \\
\widetilde{g}_{i j}=\left(\frac{x_{i j}}{z_{j}^{*}}, \frac{y_{i j}}{z_{j}^{*}}, \frac{z_{i j}}{z_{j}^{*}}\right) \quad j \in F \\
\tilde{g}_{i j}=\left(\frac{x_{j}^{-}}{z_{i j}}, \frac{x_{j}^{-}}{y_{i j}}, \frac{x_{j}^{-}}{x_{i j}}\right) \quad j \in M \\
z_{j}^{*}=\underbrace{\max }_{i} z_{i j} \quad j \in F \\
x_{j}^{-}=\underbrace{\min }_{i} x_{i j} \quad j \in M
\end{gathered}
$$

Stage 7: In the seventh stage, weighted normalized fuzzy decision matrix represented as " $\widetilde{W}$ " and shown in Equation (6) is formed.

$$
\widetilde{W}=\left[\widetilde{w}_{i j}\right]_{p x q} \quad(i=1,2, \ldots, p) \text { ve }(j=1,2, \ldots, q)
$$

In this equation (6):

$$
\widetilde{w}_{i j}=\tilde{g}_{i j}(.) \tilde{h}_{i j} \quad\left(\widetilde{w}_{i j}, \forall i, j\right)
$$

Stage 8: In this stage, the Fuzzy Positive Ideal Solution (FPIS, $U^{*}$ ) shown in equation no (7) and Fuzzy Negative Ideal Solution (FNIS, $U^{-}$) shown in equation no (8) are calculated.

$$
\begin{array}{r}
U^{*}=\left(\widetilde{w}_{1}^{*}, \widetilde{w}_{2}^{*}, \widetilde{w}_{3}^{*}, \ldots, \widetilde{w}_{j}^{*}\right) \\
U^{-}=\left(\widetilde{w}_{1}^{-}, \widetilde{w}_{2}^{-}, \widetilde{w}_{3}^{-}, \ldots, \widetilde{w}_{j}^{-}\right) \\
\widetilde{w}_{j}^{*}=(1,1,1) \\
\widetilde{w}_{j}^{-}=(0,0,0)
\end{array}
$$$$
(j=1,2, \ldots, q)
$$

Stage 9: The relative distances of each alternative from the values of FPIS and FNIS are calculated with the help of Equations (9) and (10), respectively. In the equations, $v(.,$.$) represents the distance between two triangular$ fuzzy numbers (Chen, 2000; Ecer, 2006).

$$
\begin{gathered}
v_{i}^{*}=\sum_{j=1}^{q} v\left(\widetilde{w}_{i j}, \widetilde{w}_{j}^{*}\right)(i=1,2, \ldots, p) \\
v_{i}^{-}=\sum_{j=1}^{q} v\left(\widetilde{w}_{i j}, \widetilde{w}_{j}^{-}\right)(i=1,2, \ldots, p)
\end{gathered}
$$

Stage 10: The proximity coefficient (PC) for each alternative is calculated by the formula shown in Equation (11) and the alternatives are sorted according to the proximity coefficients.

$$
P C=\frac{v_{i}^{-}}{v_{i}^{*}+v_{i}^{-}}
$$

\section{An Application for Optimal Portfolio Selection}

In this part of the study, a pool of all stocks offered by various brokerage houses for investors was created, then the common stocks were selected and sorted according to the Fuzzy TOPSIS method. A portfolio was created according to the ranking, and the performance of the portfolio was determined and compared with the performance of the portfolio constructed according to the traditional portfolio theory. In this way, the applicability of Fuzzy TOPSIS method in optimal portfolio selection has been tried to be determined.

\subsection{Ranking of Alternatives According to Fuzzy TOPSIS Method}

The general view of the optimal portfolio selection problem, which is to be solved by the fuzzy TOPSIS method, is as shown in Figure 1; and according to the Fuzzy TOPSIS Method algorithm presented in section two, the solution is shown stage by stage. 


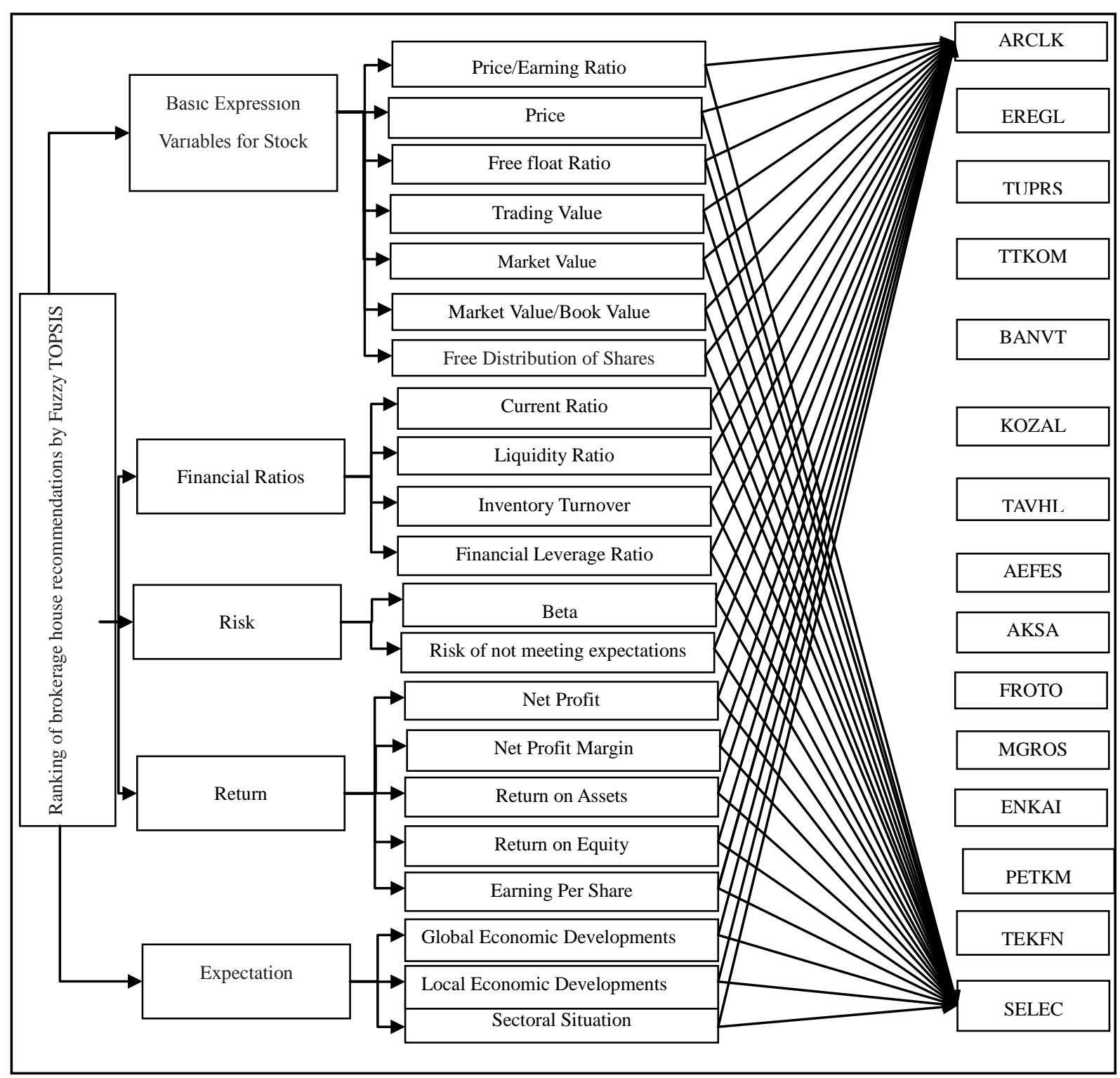

Figure 1. The usege of the optimal portfolio selection in fuzzy TOPSIS method

Stage 1: Due to the method's essence, a decision-maker group must be formed from those who are experts in stock investments. In this context, investment advisors who are experts on stock investments in portfolio management companies and people who are also experts in these areas have been requested to provide their evaluations. A three person decision making group consisting of two expert portfolio managers and one academician who received a favorable response on the basis of the negotiations was established. Therefore, the number of decision makers constituting the basis of this stage, (d), was determined as 3 . After the formation of the decision making group, the final decision on the criteria determined according to the literature was made on the basis of the interviews with the decision makers. In this context; The main explanatory variables of the stock were grouped under five main headings as "basic expression variables for stock", "financial ratios", "risk", "return" and "expectation" and a total of 21 sub-decision criteria grouped under these main headings were determined. Following this, the stocks that are common among the stocks recommended by the brokerage houses, that is, 15 stocks recommended by all brokerage houses, were determined as the decision points, or in other words, as alternatives. Table 3 below shows the decision criteria used to evaluate the alternatives and the explanations, and Table 4 shows the decision points. 
Table 3. Decision criterias and description group

\begin{tabular}{|c|c|c|}
\hline Description Group & The Name of Decision Criteria & No \\
\hline \multirow{7}{*}{ THE MAIN EXPLANATORY VARIABLES } & Price / Profit Rate & $\mathrm{C} 1$ \\
\hline & Price & $\mathrm{C} 2$ \\
\hline & Free Float Ratio & $\mathrm{C} 3$ \\
\hline & Trading Volume & $\mathrm{C} 4$ \\
\hline & Market Value & $\mathrm{C} 5$ \\
\hline & Market Value/Book Value & C6 \\
\hline & Free Distribution of Shares & $\mathrm{C} 7$ \\
\hline \multirow{4}{*}{ LIQUIDITY AND FINANCIAL STRUCTURE } & Current Ratio & $\mathrm{C} 8$ \\
\hline & Liquidity Ratio & $\mathrm{C} 9$ \\
\hline & Inventory Turnover & $\mathrm{C} 10$ \\
\hline & Financial Leverage Ratio & $\mathrm{C} 11$ \\
\hline \multirow{2}{*}{ RISK } & Beta & $\mathrm{C} 12$ \\
\hline & Risk of not meeting expectations & $\mathrm{C} 13$ \\
\hline \multirow{5}{*}{ RETURN } & Net Profit & $\mathrm{C} 14$ \\
\hline & Net Profit Margin & $\mathrm{C} 15$ \\
\hline & Return on Assets & $\mathrm{C} 16$ \\
\hline & Return on Equity & $\mathrm{C} 17$ \\
\hline & Earning Per Share & $\mathrm{C} 18$ \\
\hline \multirow{3}{*}{ EXPECTATION } & Global Economic Developments & $\mathrm{C} 19$ \\
\hline & Local Economic Developments & $\mathrm{C} 20$ \\
\hline & Sectoral Situation & $\mathrm{C} 21$ \\
\hline
\end{tabular}

Table 4. The decision points

\begin{tabular}{cccccc}
\hline Stock Name & Stock No & Stock Name & Stock No & Stock Name & Stock No \\
\hline ARCLK & A1 & KOZAL & A6 & MGROS & A11 \\
EREGL & A2 & TAV HL & A7 & ENKAI & A12 \\
TUPRS & A3 & AEFES & A8 & PETKM & A13 \\
TTKOM & A4 & AKSA & A9 & TEKFN & A14 \\
BANVT & A5 & FROTO & A10 & SELEC & A15 \\
\hline
\end{tabular}

Stage 2: After establishing the decision making group, determining decision criteria and alternatives, appropriate linguistic variables and their corresponding fuzzy numbers have been determined to evaluate the criteria and alternatives. At this stage, Chen's study has been accepted as a reference, and the linguistic variables used in Table 2 previously mentioned in the second chapter and their corresponding triangular fuzzy numbers are shown.

Stage 3: In this stage, opinions of experts on decision criteria and points were collected through linguistic variables shown in Table 2.

Stage 4: In this stage, the weight of the criteria and the significance ratings of the alternatives are calculated using the formulas shown in equations (1) and (2), where the algorithm of the Fuzzy TOPSIS method is shown.

The linguistic evaluations that experts use for decision criteria and alternatives were fuzzed using the triangular fuzzy numbers shown in Table 2. The calculations for fuzzing the linguistic variables are shown in Tables 5 and 6 below only for decision criterion $(\mathrm{C} 1)$ and decision point (A6), respectively.

Table 5. Blurring linguistic variables for decision criteria (C1)

\begin{tabular}{|c|c|c|c|c|}
\hline \multirow[b]{2}{*}{ Decision Makers (DM) } & \multirow[b]{2}{*}{ Linguistic Variable } & \multicolumn{3}{|c|}{$\mathrm{C} 1$} \\
\hline & & $\mathrm{x}$ & $\mathrm{y}$ & $\mathrm{Z}$ \\
\hline DM1 & MH & 0.5 & 0.7 & 0.9 \\
\hline DM2 & VH & 0.9 & 1.0 & 1.0 \\
\hline DM3 & $\mathrm{H}$ & 0.7 & 0.9 & 1.0 \\
\hline \multicolumn{2}{|c|}{ Average } & 0.7 & 0.866667 & 0.966667 \\
\hline
\end{tabular}

“C1: Price / Profit Ratio" Calculation of Weight of Decision Criteria:

$\tilde{\mathrm{h}}_{1}=(0.5+0.9+0.7) / 3=0.7$ 
$\tilde{\mathrm{h}}_{1}=(0.7+1.0+0.9) / 3=0.866667$

$\tilde{\mathrm{h}}_{1}=(0.9+1.0+1.0) / 3=0.966667$

$\tilde{\mathrm{h}}_{1}=(0.7 ; 0.866667 ; 0.96667)$

$\tilde{\mathrm{h}}_{1}=(0.7 ; 0.866667 ; 0.96667)$

Table 6. Determining the significance of the decision point (A6) and blurring it

\begin{tabular}{|c|c|c|c|c|}
\hline \multirow[b]{2}{*}{ Decision Makers } & \multirow[b]{2}{*}{ Linguistic Variable } & \multicolumn{3}{|c|}{$\mathrm{C} 1$} \\
\hline & & Low & Medium & Upper \\
\hline DM1 & MG & 5 & 7 & 9 \\
\hline DM2 & MP & 1 & 3 & 5 \\
\hline DM3 & $\mathrm{G}$ & 7 & 9 & 10 \\
\hline \multicolumn{2}{|c|}{ Average } & 4.3333 & 6.3333 & 8 \\
\hline
\end{tabular}

Determination of the Degree of Importance of "A6: Koza Gold Decision Point" According to "C1: Price / Profit Rate" and Fuzzing:

$\tilde{t}_{61}=(5+1+7) / 3=4.3333$;

$\tilde{t}_{61}=(7+3+9) / 3=6.3333$;

$\tilde{t}_{61}=(9+5+10) / 3=8$

$\tilde{t}_{61}=(4.3333 ; 6.3333 ; 8.0000)$

Stage 5: In this stage, the fuzzy decision and fuzzy weight matrices are shown by equations (3) and (4) at the part where the algorithm of Fuzzy TOPSIS method is. The fuzzy decision matrix, represented by, $\tilde{S}$ is not shown because it was too large. The resulting fuzzy weight matrix is shown in Table 7.

Table 7. Fuzzy weight matrix

\begin{tabular}{|c|c|c|c|c|c|c|c|}
\hline \multirow[b]{2}{*}{ Criteria } & \multicolumn{3}{|c|}{ Tringular Fuzzy Number } & \multirow[b]{2}{*}{ Criteria } & \multicolumn{3}{|c|}{ Tringular Fuzzy Number } \\
\hline & $\mathrm{x}$ & $\mathrm{y}$ & $\mathrm{z}$ & & $\mathrm{x}$ & $\mathrm{y}$ & $\mathrm{z}$ \\
\hline $\mathrm{C} 1$ & 0.700000 & 0.866667 & 0.966667 & $\mathrm{C} 12$ & 0.466667 & 0.633333 & 0.766667 \\
\hline $\mathrm{C} 2$ & 0.466667 & 0.600000 & 0.700000 & $\mathrm{C} 13$ & 0.433333 & 0.633333 & 0.833333 \\
\hline $\mathrm{C} 3$ & 0.266667 & 0.433333 & 0.633333 & $\mathrm{C} 14$ & 0.333333 & 0.466667 & 0.633333 \\
\hline $\mathrm{C} 4$ & 0.633333 & 0.800000 & 0.933333 & $\mathrm{C} 15$ & 0.500000 & 0.700000 & 0.900000 \\
\hline $\mathrm{C} 5$ & 0.700000 & 0.866667 & 0.966667 & $\mathrm{C} 16$ & 0.566667 & 0.766667 & 0.933333 \\
\hline C6 & 0.700000 & 0.866667 & 0.966667 & $\mathrm{C} 17$ & 0.700000 & 0.866667 & 0.966667 \\
\hline $\mathrm{C} 7$ & 0.266667 & 0.433333 & 0.633333 & $\mathrm{C} 18$ & 0.700000 & 0.866667 & 0.966667 \\
\hline $\mathrm{C} 8$ & 0.266667 & 0.400000 & 0.566667 & $\mathrm{C} 19$ & 0.566667 & 0.733333 & 0.833333 \\
\hline C9 & 0.266667 & 0.400000 & 0.566667 & $\mathrm{C} 20$ & 0.566667 & 0.733333 & 0.833333 \\
\hline $\mathrm{C} 10$ & 0.266667 & 0.400000 & 0.566667 & $\mathrm{C} 21$ & 0.633333 & 0.800000 & 0.900000 \\
\hline $\mathrm{C} 11$ & 0.566667 & 0.733333 & 0.866667 & & & & \\
\hline
\end{tabular}

Stage 6: In the sixth stage values normalized based on the fuzzy decision matrix were calculated and normalized fuzzy decision matrix, shown in equation (5) at the part where Fuzzy TOPSIS method algorithm is, was generated. The normalized fuzzy decision matrix cannot be shown due to its size; only the normalization process of "A6: Koza Gold" decision point according to "C1: Price / Profit Rate" was given below.

$\tilde{\mathrm{g}}_{61}=(4.3333 / 8.66667 ; 6.3333 / 8.66667 ; 8$ / 8.66667 $)$

$\tilde{\mathrm{g}}_{61}=(0.5 ; 0.73 ; 0.92)$

Stage 7: In this stage, the weighted normalized fuzzy values were calculated using the normalized fuzzy decision matrix generated in the sixth stage, and a weighted normalized fuzzy decision matrix represented by $\widetilde{W}$ in Equation (6) was generated but could not be shown due to its size. As an example of the calculation of the weighted normalized values, only the weighted normalization process of "A6: Koza Gold" alternative to "C1: Price/Profit Rate" was shown.

Calculation of Weighted Normalized Value of "A6: Koza Gold" Alternative by "C1: Price / Profit Rate":

$\tilde{\mathrm{g}}_{6}=(0.5 ; 0.73 ; 0.92)$ 
$\tilde{\mathrm{h}}_{1}=(0.7 ; 0.866667 ; 0.96667)$

$\widetilde{\mathrm{w}}_{61}=(0.5 * 0.7 ; 0.73 * 0.866667 ; 0.92 * 0.966667)$

$\widetilde{\mathrm{w}}_{61}=(0.35 ; 6.33 ; 0.89)$

Stage 8: In the eighth stage, Fuzzy Positive value represented as $\left(U^{*}\right)$ in Equation (7) and Negative Ideal Solution values represented as $\left(U^{-}\right)$in Equation (8) were calculated and shown in Tables 8 and 9, respectively.

Table 8. FPIS values $\left(\mathrm{U}^{*}\right)$

\begin{tabular}{|c|c|c|c|c|c|c|c|c|c|c|c|c|c|c|c|}
\hline \multirow[b]{2}{*}{ Criteria } & \multicolumn{15}{|c|}{ Decision Points } \\
\hline & $\mathrm{A} 1$ & $\mathrm{~A} 2$ & $\mathrm{~A} 3$ & $\mathrm{~A} 4$ & A5 & A6 & $\mathrm{A} 7$ & A8 & A9 & A10 & A11 & A12 & A13 & A14 & A15 \\
\hline $\mathrm{C} 1$ & 0.41 & 0.55 & 0.37 & 0.32 & 0.93 & 0.37 & 0.36 & 0.42 & 0.37 & 0.37 & 0.93 & 0.32 & 0.32 & 0.41 & 0.37 \\
\hline $\mathrm{C} 2$ & 0.35 & 0.31 & 0.38 & 0.28 & 0.50 & 0.31 & 0.28 & 0.35 & 0.38 & 0.35 & 0.59 & 0.28 & 0.31 & 0.38 & 0.28 \\
\hline $\mathrm{C} 3$ & 0.34 & 0.39 & 0.30 & 0.30 & 0.38 & 0.39 & 0.34 & 0.30 & 0.29 & 0.39 & 0.43 & 0.34 & 0.30 & 0.32 & 0.32 \\
\hline $\mathrm{C} 4$ & 0.54 & 0.37 & 0.59 & 0.41 & 0.85 & 0.68 & 0.33 & 0.54 & 0.50 & 0.50 & 0.64 & 0.33 & 0.65 & 0.68 & 0.55 \\
\hline $\mathrm{C} 5$ & 0.55 & 0.59 & 0.70 & 0.72 & 0.70 & 0.37 & 0.42 & 0.50 & 0.41 & 0.33 & 0.40 & 0.45 & 0.45 & 0.32 & 0.50 \\
\hline C6 & 0.33 & 0.37 & 0.33 & 0.47 & 0.74 & 0.42 & 0.56 & 0.12 & 0.52 & 0.47 & 0.69 & 0.62 & 0.34 & 0.52 & 0.62 \\
\hline $\mathrm{C} 7$ & 0.43 & 0.44 & 0.36 & 0.32 & 0.41 & 0.41 & 0.35 & 0.35 & 0.37 & 0.40 & 0.41 & 0.43 & 0.41 & 0.38 & 0.38 \\
\hline $\mathrm{C} 8$ & 0.37 & 0.47 & 0.30 & 0.30 & 0.39 & 0.30 & 0.25 & 0.32 & 0.39 & 0.32 & 0.34 & 0.41 & 0.42 & 0.37 & 0.32 \\
\hline C9 & 0.35 & 0.47 & 0.27 & 0.29 & 0.47 & 0.33 & 0.33 & 0.42 & 0.42 & 0.31 & 0.35 & 0.45 & 0.44 & 0.29 & 0.29 \\
\hline C10 & 0.32 & 0.26 & 0.37 & 0.35 & 0.39 & 0.37 & 0.37 & 0.29 & 0.35 & 0.30 & 0.35 & 0.46 & 0.30 & 0.32 & 0.35 \\
\hline C11 & 0.43 & 0.42 & 0.47 & 0.47 & 0.42 & 0.39 & 0.43 & 0.35 & 0.42 & 0.39 & 0.39 & 0.47 & 0.39 & 0.39 & 0.47 \\
\hline $\mathrm{C} 12$ & 0.33 & 0.33 & 0.33 & 0.33 & 0.41 & 0.33 & 0.37 & 0.32 & 0.40 & 0.37 & 0.37 & 0.53 & 0.33 & 0.33 & 0.33 \\
\hline $\mathrm{C} 13$ & 0.47 & 0.43 & 0.43 & 0.43 & 0.40 & 0.47 & 0.47 & 0.43 & 0.47 & 0.40 & 0.47 & 0.47 & 0.47 & 0.40 & 0.47 \\
\hline C14 & 0.34 & 0.40 & 0.45 & 0.35 & 0.61 & 0.37 & 0.32 & 0.45 & 0.32 & 0.29 & 0.61 & 0.40 & 0.46 & 0.29 & 0.34 \\
\hline C15 & 0.44 & 0.44 & 0.40 & 0.40 & 0.87 & 0.71 & 0.40 & 0.51 & 0.40 & 0.37 & 0.87 & 0.51 & 0.63 & 0.51 & 0.55 \\
\hline C16 & 0.42 & 0.44 & 0.34 & 0.44 & 0.90 & 0.57 & 0.48 & 0.48 & 0.37 & 0.34 & 0.90 & 0.57 & 0.41 & 0.57 & 0.61 \\
\hline C17 & 0.35 & 0.34 & 0.47 & 0.61 & 0.94 & 0.61 & 0.42 & 0.52 & 0.33 & 0.30 & 0.94 & 0.56 & 0.33 & 0.61 & 0.71 \\
\hline C18 & 0.51 & 0.56 & 0.56 & 0.72 & 0.94 & 0.65 & 0.51 & 0.72 & 0.23 & 0.42 & 0.91 & 0.75 & 0.52 & 0.51 & 0.83 \\
\hline C19 & 0.35 & 0.35 & 0.39 & 0.39 & 0.39 & 0.39 & 0.39 & 0.39 & 0.39 & 0.39 & 0.39 & 0.39 & 0.39 & 0.39 & 0.39 \\
\hline C20 & 0.31 & 0.35 & 0.35 & 0.39 & 0.39 & 0.39 & 0.39 & 0.39 & 0.39 & 0.39 & 0.39 & 0.39 & 0.39 & 0.39 & 0.39 \\
\hline $\mathrm{C} 21$ & 0.33 & 0.37 & 0.37 & 0.41 & 0.41 & 0.41 & 0.41 & 0.41 & 0.41 & 0.41 & 0.41 & 0.41 & 0.41 & 0.41 & 0.41 \\
\hline Total & 8.26 & 8.66 & 8.53 & 8.71 & 12.43 & 9.24 & 8.18 & 9.20 & 8.14 & 7.80 & 11.78 & 9.53 & 8.68 & 8.79 & 9.48 \\
\hline
\end{tabular}

Table 9. FNIS values $\left(\mathrm{U}^{-}\right)$

\begin{tabular}{|c|c|c|c|c|c|c|c|c|c|c|c|c|c|c|c|}
\hline \multirow[b]{2}{*}{ Criteria } & \multicolumn{15}{|c|}{ Decision Points } \\
\hline & A1 & $\mathrm{A} 2$ & A3 & $\mathrm{A} 4$ & A5 & A6 & A7 & A8 & A9 & A10 & A11 & A12 & A13 & A14 & A15 \\
\hline $\mathrm{C} 1$ & 0.66 & 0.49 & 0.68 & 0.75 & 0.06 & 0.68 & 0.67 & 0.62 & 0.68 & 0.68 & 0.06 & 0.73 & 0.73 & 0.66 & 0.68 \\
\hline $\mathrm{C} 2$ & 0.41 & 0.45 & 0.37 & 0.50 & 0.22 & 0.45 & 0.50 & 0.41 & 0.36 & 0.41 & 0.14 & 0.50 & 0.45 & 0.38 & 0.50 \\
\hline $\mathrm{C} 3$ & 0.33 & 0.26 & 0.38 & 0.38 & 0.28 & 0.26 & 0.33 & 0.38 & 0.39 & 0.26 & 0.22 & 0.33 & 0.38 & 0.36 & 0.36 \\
\hline $\mathrm{C} 4$ & 0.46 & 0.67 & 0.41 & 0.62 & 0.13 & 0.28 & 0.71 & 0.46 & 0.51 & 0.51 & 0.37 & 0.71 & 0.32 & 0.32 & 0.46 \\
\hline $\mathrm{C} 5$ & 0.41 & 0.36 & 0.25 & 0.21 & 0.25 & 0.58 & 0.52 & 0.45 & 0.55 & 0.62 & 0.56 & 0.52 & 0.50 & 0.66 & 0.46 \\
\hline C6 & 0.70 & 0.65 & 0.70 & 0.53 & 0.26 & 0.59 & 0.39 & 0.26 & 0.49 & 0.53 & 0.31 & 0.37 & 0.66 & 0.49 & 0.37 \\
\hline C7 & 0.22 & 0.17 & 0.33 & 0.37 & 0.21 & 0.21 & 0.29 & 0.29 & 0.28 & 0.24 & 0.21 & 0.22 & 0.24 & 0.29 & 0.25 \\
\hline $\mathrm{C} 8$ & 0.25 & 0.12 & 0.32 & 0.32 & 0.22 & 0.32 & 0.39 & 0.30 & 0.21 & 0.3 & 0.27 & 0.19 & 0.17 & 0.25 & 0.30 \\
\hline C9 & 0.27 & 0.13 & 0.38 & 0.36 & 0.13 & 0.30 & 0.29 & 0.18 & 0.18 & 0.32 & 0.27 & 0.16 & 0.16 & 0.35 & 0.36 \\
\hline $\mathrm{C} 10$ & 0.29 & 0.37 & 0.22 & 0.26 & 0.20 & 0.23 & 0.22 & 0.31 & 0.26 & 0.32 & 0.26 & 0.12 & 0.32 & 0.29 & 0.26 \\
\hline C11 & 0.37 & 0.35 & 0.30 & 0.32 & 0.35 & 0.42 & 0.37 & 0.46 & 0.35 & 0.42 & 0.40 & 0.32 & 0.40 & 0.42 & 0.32 \\
\hline $\mathrm{C} 12$ & 0.48 & 0.48 & 0.48 & 0.48 & 0.38 & 0.48 & 0.44 & 0.47 & 0.38 & 0.43 & 0.44 & 0.25 & 0.48 & 0.48 & 0.48 \\
\hline C13 & 0.35 & 0.39 & 0.39 & 0.39 & 0.44 & 0.35 & 0.35 & 0.39 & 0.35 & 0.44 & 0.35 & 0.35 & 0.35 & 0.44 & 0.35 \\
\hline C14 & 0.38 & 0.31 & 0.23 & 0.37 & 0.04 & 0.34 & 0.40 & 0.23 & 0.40 & 0.44 & 0.04 & 0.30 & 0.23 & 0.44 & 0.38 \\
\hline C15 & 0.57 & 0.58 & 0.62 & 0.62 & 0.05 & 0.25 & 0.62 & 0.49 & 0.62 & 0.65 & 0.05 & 0.49 & 0.34 & 0.49 & 0.44 \\
\hline C16 & 0.60 & 0.60 & 0.71 & 0.60 & 0.05 & 0.45 & 0.55 & 0.55 & 0.67 & 0.71 & 0.05 & 0.45 & 0.63 & 0.45 & 0.40 \\
\hline $\mathrm{C} 17$ & 0.69 & 0.71 & 0.57 & 0.43 & 0.06 & 0.43 & 0.63 & 0.52 & 0.73 & 0.77 & 0.06 & 0.48 & 0.73 & 0.43 & 0.32 \\
\hline C18 & 0.53 & 0.48 & 0.48 & 0.32 & 0.06 & 0.37 & 0.53 & 0.32 & 0.81 & 0.64 & 0.09 & 0.27 & 0.52 & 0.53 & 0.18 \\
\hline C19 & 0.38 & 0.38 & 0.33 & 0.33 & 0.33 & 0.33 & 0.33 & 0.33 & 0.33 & 0.33 & 0.33 & 0.33 & 0.33 & 0.33 & 0.33 \\
\hline $\mathrm{C} 20$ & 0.39 & 0.35 & 0.35 & 0.31 & 0.31 & 0.31 & 0.31 & 0.31 & 0.31 & 0.31 & 0.31 & 0.31 & 0.31 & 0.31 & 0.31 \\
\hline $\mathrm{C} 21$ & 0.41 & 0.38 & 0.38 & 0.33 & 0.33 & 0.33 & 0.33 & 0.33 & 0.33 & 0.33 & 0.33 & 0.33 & 0.33 & 0.33 & 0.33 \\
\hline Total & 9.15 & 8.68 & 8.89 & 8.77 & 4.36 & 7.98 & 9.18 & 8.05 & 9.20 & 9.67 & 5.14 & 7.73 & 8.59 & 8.69 & 7.84 \\
\hline
\end{tabular}


Stage 9: In this stage, at the part where the algorithm of the method is explained, the distance of the decision points to FPIS values represented as $\left(v_{i}^{*}\right)$ in Equation (9) and FNIS values represented as $\left(v_{i}^{-}\right)$in Equation (10) were calculated and shown in Table 10.

Stage 10: The distances calculated with the formulas in Equations (9) and (10) are used in the formula shown in the formula depicted as equation (11) in the part where the algorithm of the method is included and the proximity coefficient of each decision point was calculated $\left(\mathrm{PC}_{\mathrm{i}}\right)$. The calculation of the proximity coefficient of the "A6: Koza Gold" decision point alone is shown below; calculated proximity coefficients of other decision points and the ranking based on these coefficients are given in Table 10.

$\mathrm{PC}_{6}=9.15 /(8.26+9.15) \quad \mathrm{PC}_{6}=0.5255$

Table 10. Proximity coefficients of decision points and ranking according to these coefficients

\begin{tabular}{cccccc}
\hline Alternative Name & Alternative No & $\mathrm{V}_{\mathrm{i}}{ }^{*}$ & $\mathrm{~V}_{\mathrm{i}}{ }^{-}$ & $\mathrm{PC}_{\mathrm{i}}$ & Ranking \\
\hline FROTO & $\mathrm{A} 10$ & 7.797 .825 & 9.666 .975 & 0.553512 & 1 \\
AKSA & $\mathrm{A} 9$ & 8.138 .807 & 9.201 .987 & 0.530655 & 2 \\
TAVHL & $\mathrm{A} 7$ & 8.183 .940 & 917.706 & 0.528602 & 3 \\
ARÇLK & $\mathrm{A} 1$ & 8.258 .738 & 9.146 .915 & 0.525514 & 4 \\
TUPRS & $\mathrm{A} 3$ & 8.533 .223 & 8.886 .848 & 0.510150 & 5 \\
TTKOM & $\mathrm{A} 4$ & 8.714 .264 & 8.771 .089 & 0.501625 & 6 \\
EREGL & $\mathrm{A} 2$ & 8.656 .875 & 8.675 .879 & 0.500548 & 7 \\
PETKM & $\mathrm{A} 13$ & 8.681 .925 & 8.587 .755 & 0.497274 & 8 \\
TEKFN & $\mathrm{A} 14$ & 8.788 .336 & 8.685 .542 & 0.497059 & 9 \\
AEFES & $\mathrm{A} 8$ & 9.197 .002 & 8.045 .323 & 0.466603 & 10 \\
KOZAL & $\mathrm{A} 6$ & 9.242 .565 & 7.976 .255 & 0.463229 & 11 \\
SELEC & $\mathrm{A} 15$ & 9.479 .200 & 7.843 .796 & 0.452797 & 12 \\
ENKAI & $\mathrm{A} 12$ & 9.528 .863 & 7.729 .558 & 0.447872 & 13 \\
MGROS & $\mathrm{A} 11$ & 11.777 .610 & 5.141 .970 & 0.303907 & 14 \\
BANVT & $\mathrm{A} 5$ & 12.433 .540 & 4.359 .575 & 0.259605 & 15 \\
\hline
\end{tabular}

In Figure 2, the ranking of decision points according to the proximity coefficients is shown in graph.

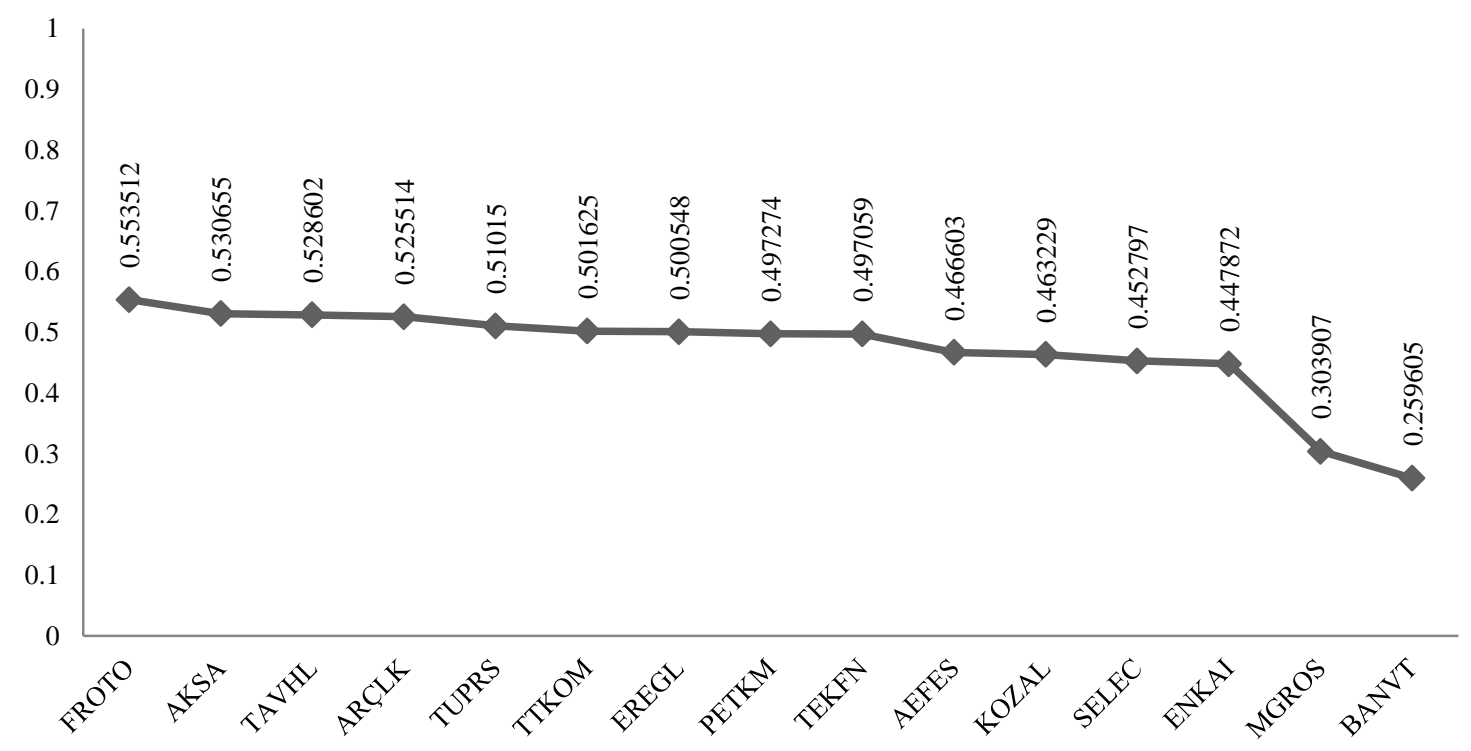

Figure 2. Ranking according to proximity coefficients of decision points

According to the results obtained through the evaluation of stocks recommended by brokerage houses via Fuzzy TOPSIS method, 15 stocks that are subjects of this study are sorted in the form of FROTO>AKSA> TAV HL > ARCLK > TUPRS > TTKOM > EREGL $>$ PETKM $>$ TEKFN $>$ AEFES > KOZAL > SELEC > ENKAI > 
MGROS > BANVIT. In addition, the results revealed that the decision makers consider the criteria C5, C18, C1, C6 and C17 significant when evaluating the stocks. Ranking of the 21 decision criteria in their order of importance according to the decision makers is shown in Table 11.

Table 11. Order of importance according to decision makers of decision criteria

\begin{tabular}{cccccc}
\hline Criteria No & Criteria Name & Order of Imp. & Criteria No & Criteria Name & Order of Imp. \\
\hline C5 & Market Value & 1 & C15 & Net Profit Margin & 7 \\
C18 & Earning Per Share & 1 & C13 & Risk of not meeting expectations & 8 \\
C1 & Price/Earning Ratio & 1 & C12 & Beta & 9 \\
C6 & Market Value/Book Value & 1 & C2 & Price & 10 \\
C17 & Return on Equity & 1 & C14 & Net Profit & 11 \\
C4 & Trading Volume & 2 & C3 & Free Float Ratio & 12 \\
C21 & Sectoral Situation & 3 & C7 & Free Distribution of Shares \% & 12 \\
C16 & Return on Assets & 4 & C8 & Current Ratio & 13 \\
C11 & Financial Leverage Ratio & 5 & C9 & Liquidity Ratio & 13 \\
C19 & Global Economic Developments & 6 & C10 & Inventory Turnover & 13 \\
C20 & Local Economic Developments & 6 & & & \\
\hline
\end{tabular}

\subsection{Portfolio Creation According to the Ranking Obtained from the Fuzzy TOPSIS Method}

While creating the portfolio based on listings of the investment recommendations of the brokerage houses determined in accordance with the Fuzzy TOPSIS method, in order to calculate the diversification and weights of the stocks to be included in the portfolio, $\mathrm{PC}_{\mathrm{i}}$ value of each stock has been deducted from Average $\mathrm{PC}_{\mathrm{i}}$ Based on these differences, the alternatives of bipartite, tripartite, quadripartite stock certificates that are the basis of diversification are determined. Portfolio weights of each alternative are calculated as a percentage of these differences. The determined portfolios and the weights of their components are shown in Table 12.

Table 12. Portfolios and components of fuzzy TOPSIS method

\begin{tabular}{|c|c|c|c|c|c|c|c|}
\hline \multirow{2}{*}{ Stock Name } & \multirow{2}{*}{$\mathrm{PC}_{\mathrm{i}}$} & \multirow{2}{*}{$\mathrm{PC}_{\mathrm{i}} \cdot \mathrm{APC}_{\mathrm{i}}$} & \multicolumn{5}{|c|}{ Weights of Portfolio and Portfolio Components } \\
\hline & & & 6's (\%) & 5 's $(\%)$ & 4's (\%) & 3's $(\%)$ & 2's (\%) \\
\hline FROTO & 0.553512 & 0.084249 & 25.1881 & 27.8862 & 32.2508 & 41.1011 & 57.8471 \\
\hline AKSA & 0.530655 & 0.061392 & 18.3545 & 20.3205 & 23.5010 & 29.9502 & 42.1529 \\
\hline TAVHL & 0.528602 & 0.059339 & 17.7407 & 19.6410 & 22.7151 & 28.9486 & \\
\hline ARÇLK & 0.525514 & 0.056251 & 16.8174 & 18.6189 & 21.5330 & & \\
\hline TUPRS & 0.510150 & 0.040887 & 12.2240 & 13.5334 & & & \\
\hline TTKOM & 0.501625 & 0.032362 & 9.6753 & & & & \\
\hline EREGL & 0.500548 & 0.031285 & & & & & \\
\hline PETKM & 0.497274 & 0.028011 & & & & & \\
\hline TEKFN & 0.497059 & 0.027796 & & & & & \\
\hline AEFES & 0.466603 & -0.002660 & & & & & \\
\hline KOZAL & 0.463229 & -0.006030 & & & & & \\
\hline SELEC & 0.452797 & -0.016470 & & & & & \\
\hline ENKAI & 0.447872 & -0.021390 & & & & & \\
\hline MGROS & 0.303907 & -0.165360 & & & & & \\
\hline BANVT & 0.259605 & -0.209660 & & & & & \\
\hline Avarege $\left(\mathrm{APC}_{\mathrm{i}}\right)$ & 0.469263 & & & & & & \\
\hline
\end{tabular}

\subsubsection{Determining Risk, Profit and Performance of Portfolios Created}

The risk, return and performance indexes for alternative portfolios with different component numbers are calculated based on the PC ranking obtained from the decision criteria as shown in Table 12. The basis of the calculation were the average prices of the stock certificates in the brokerage house recommendations between 01.01.2010-01.03.2017 and were obtained from BIST.

In calculations made with Excel Solver, Markowitz's Modern Portfolio Theory criteria were taken as the portfolio model. The explanations for the operations carried out in this context are briefly as follows: 
Return: Is the percentage change in the stock certificate within a certain period and is calculated by the formula $\frac{p_{n+1}}{P_{n}}-1$. Return calculation is to determine the net capital gain or loss that the stock investment shows.

Portfolio Return: The future course of financial assets is based on the assumption that it will exhibit its past performance and refers to the weighted average of the expected return of a stock certificate by its proportion in the portfolio. The formula used in the calculations is shown in equation (12) (Aksoy \& Tanrioven, 2007).

$$
\begin{gathered}
R_{p}=\sum_{i=1}^{n} R_{i} x_{1}=R_{i} x_{1}+R_{2} x_{2}+\cdots .+R_{n} x_{n} \\
\sum_{i=1}^{n} x_{i}=x_{1}+x_{2}+\ldots \ldots \ldots \ldots \ldots \ldots+x_{n}=1 \text { ve } 0 \leq x \quad i \leq 1
\end{gathered}
$$

Risk: Risk is the probability of facing an undesired event or effect in the future and represents the standard deviation that shows the probability of having less return than expected. The formula used in the calculations is shown in equation (13) (Aksoy \& Tanrioven, 2007).

$$
\sigma_{p}=\sqrt{\sum_{i=1}^{n} x_{i}^{2} \sigma_{i}^{2}+2 \sum_{i=1}^{n} \sum_{i<j} x_{i} x_{j} \operatorname{Cov}_{i j}}
$$

Here $\sigma_{p}$, represents the risk of portfolio, $\sigma_{i}$, represents the variance of the returns of the i'th stock, and $\operatorname{Cov}_{i j}$, represents the covariance between $i$ and $j$ 'th stocks.

Alpha Coefficient: It is a coefficient that measures the non-systematic risk of the price movement of securities and shows the return relative to the risk. If it is less than zero, it indicates that the expectation was smaller relative to the risk taken; if it is equal to zero, it indicates that the return is equal to the expectation relative to the risk; if it is larger than zero, it indicates that the return is higher than expectation relative to the risk taken.

The alpha coefficient, which is essentially regarded as a criterion of non-systematic risk, has an important place in modern portfolio theory due to its ability to be maintained by diversification. Because, in the portfolio selection, the Alpha coefficient is a measure of the contribution of the selection to the portfolio and has a linear correlation with the portfolio performance and is considered as an indicator of portfolio performance (Reilly \& Brown, 2012).

Beta Coefficient: The beta coefficient is used to compare the market risk and stock certificate risk, and is a measure of volatility and systematic risk. The beta coefficient, which represents the slope of the regression line, is the ratio of the covariance of market return and stock return to the variation of market return and is calculated by the equation (14) (Ross et al., 2005).

$$
\begin{gathered}
\beta=\operatorname{COV}\left(R_{p} R_{i}\right) / \operatorname{VAR}\left(R_{p}\right) \\
R_{p} \text { is market return and } R_{i} \text { is Stock Return }
\end{gathered}
$$

Sharpe Ratio: It assumes that there is a linear relationship between all securities and the market in which they are traded. Thus, the relationship between security and market is represented as a simple linear regression line. This performance criteria, claimed by William Sharpe who considered portfolio risk, has a simple applicability and is widely used in performance evaluation. The Sharpe Ratio, which is one of the risk-adjusted performance measurement techniques, is the ratio of the risk premium defined as the difference between the expected value of the portfolio and the risk-free interest rate to the standard deviation of the portfolio, and is calculated based on equation (15) (Sharpe, 1966).

$$
\begin{gathered}
\text { SI }=\frac{r_{m}-r_{f}}{\sigma_{p}} \\
r_{p}: \text { Expected return of portfolio } \\
r_{f}: \text { Risk Free Ratio } \\
\sigma_{p}: \text { Standard deviation of portfolio }
\end{gathered}
$$

\begin{tabular}{|c|c|c|c|c|c|c|c|c|c|c|c|c|}
\hline \multicolumn{5}{|c|}{ PORTFOLIO COMPONENTS } & \multicolumn{8}{|c|}{ PORTFOLIO } \\
\hline $\begin{array}{l}\text { Stock } \\
\text { Code }\end{array}$ & $\begin{array}{c}\text { Weight } \\
(\%)\end{array}$ & Return & Risk & Beta & $\begin{array}{c}\text { Return } \\
(\%)\end{array}$ & $\begin{array}{l}\text { Risk } \\
(\%)\end{array}$ & Beta & $\begin{array}{l}\text { Alfa } \\
(\%)\end{array}$ & $\begin{array}{l}\mathrm{R}^{2} \\
(\%)\end{array}$ & $\begin{array}{c}\text { Sharpe } \\
\text { Ratio }\end{array}$ & $\begin{array}{c}\text { Market } \\
\text { Risk }\end{array}$ & $\begin{array}{c}\text { Non-systematic } \\
\text { Risk }\end{array}$ \\
\hline AKSA & 42.1529 & 0.1076 & 20.521 & 0.7672 & 0.1191 & 17.327 & 0.7943 & 0.0830 & 44.8358 & 0.0545 & 11.602 & 12.869 \\
\hline FROTO & 57.8471 & 0.1275 & 21.405 & 0.8140 & & & & & & & & \\
\hline
\end{tabular}

Portfolios, components and portfolio risk, return and performance calculation results based on Fuzzy TOPSIS method are presented in Table 13-17.

Table 13. Portfolio components and results created by fuzzy TOPSIS 1 
In the study performed towards the applicability of Fuzzy TOPSIS method in selecting the optimal portfolio, the data of the bipartite portfolio formed according to Fuzzy TOPSIS for a comparison along the perspective of risk, performance and return according to the modern portfolio theory by Markowitz, which is widely accepted in finance literature, are presented in Table 13. The portfolio, which had a return of $0.1191 \%$, had a risk of $1.7327 \%$, its Beta value was 0.7943 and Alpha value was $0.0830 \%$. Although the calculated values are theoretically acceptable, but for the requirement of proving its applicability in the literature, it would be more appropriate to compare them with the results of the portfolio component of Table 19, which is determined according to Markowitz's and gives the portfolio component at the same risk level. After the calculations to be performed based on Markowitz, the comparisons are made under the title Portfolio Evaluation and Comparison.

Table 14. Portfolio components and results created by fuzzy TOPSIS 2

\begin{tabular}{|c|c|c|c|c|c|c|c|c|c|c|c|c|}
\hline \multicolumn{5}{|c|}{ PORTFOLIO COMPONENTS } & \multicolumn{8}{|c|}{ PORTFOLIO } \\
\hline $\begin{array}{l}\text { Stock } \\
\text { Code }\end{array}$ & $\begin{array}{l}\text { Weight } \\
(\%)\end{array}$ & Return & Risk & Beta & $\begin{array}{c}\text { Return } \\
(\%)\end{array}$ & $\begin{array}{l}\text { Risk } \\
(\%)\end{array}$ & Beta & $\begin{array}{c}\text { Alpha } \\
(\%)\end{array}$ & $\begin{array}{l}\mathrm{R}^{2} \\
(\%) \\
\end{array}$ & $\begin{array}{c}\text { Sharpe } \\
\text { Ratio }\end{array}$ & $\begin{array}{c}\text { Market } \\
\text { Risk }\end{array}$ & $\begin{array}{c}\text { Non-systematic } \\
\text { Risk } \\
\end{array}$ \\
\hline AKSA & 29.9502 & 0.1076 & 20.521 & 0.7672 & 0.1186 & 15.807 & 0.7869 & 0.0827 & 52.8840 & 0.0595 & 11.495 & 10.850 \\
\hline FROTO & 41.1011 & 0.1275 & 21.405 & 0.8140 & & & & & & & & \\
\hline TAVHL & 28.9486 & 0.1174 & 22.104 & 0.7689 & & & & & & & & \\
\hline
\end{tabular}

Table 14 presents the risk, return and performance indicator data for the portfolio and the component of the tripartite portfolio calculated based on Fuzzy TOPSIS. According to the indicator data of portfolio components generated, portfolio return is $0.1186 \%$ and its risk is calculated as $1.5807 \%$. Its values in terms of performance are a Sharpe ratio of 0.0595 and an Alpha value of $0.0827 \%$, and acceptable. However, for the applicability of the method in selecting the optimal portfolio, comparison with Markowitz's portfolio components is an iterable requirement.

Table 15. Portfolio components and results created by fuzzy TOPSIS 3

\begin{tabular}{ccccccccccccc}
\hline \multicolumn{3}{c}{ PORTFOLIO COMPONENTS } & \multicolumn{1}{c}{ PORTFOLIO } \\
\hline Stock Code & $\begin{array}{c}\text { Weight } \\
(\%)\end{array}$ & Return & Risk & Beta & $\begin{array}{c}\text { Return } \\
(\%)\end{array}$ & $\begin{array}{c}\text { Risk } \\
(\%)\end{array}$ & Beta & $\begin{array}{c}\text { Alpha } \\
(\%)\end{array}$ & $\begin{array}{c}\mathrm{R}^{2} \\
(\%)\end{array}$ & $\begin{array}{c}\text { Sharpe } \\
\text { Ratio }\end{array}$ & $\begin{array}{c}\text { Market } \\
\text { Risk }\end{array}$ & $\begin{array}{c}\text { Non-systemat } \\
\text { ic Risk }\end{array}$ \\
\hline AKSA & 23.5010 & 0.1076 & 20.521 & 0.7672 & 0.1126 & 15.429 & 0.8256 & 0.0760 & 61.0887 & 0.0570 & 12.059 & 0.9625 \\
ARCLK & 21.5330 & 0.0905 & 21.765 & 0.9664 & & & & & & & & \\
FROTO & 32.2508 & 0.1275 & 21.405 & 0.8140 & & & & & & & & \\
TAVHL & 22.7151 & 0.1174 & 22.104 & 0.7689 & & & & & & & & \\
\hline
\end{tabular}

In Table 15, data of the four component portfolio formed based on Fuzzy TOPSIS are presented. The portfolio formed has a return level of $0.1126 \%$ and its risk is $1.5429 \%$. In terms of performance criteria, the resulting 0.0570 Sharpe Ratio indicates a good efficiency.

Table 16. Portfolio components and results created by fuzzy TOPSIS 4

\begin{tabular}{ccccccccccccc}
\hline \multicolumn{3}{c}{ PORTFOLIO COMPONENTS } & \multicolumn{1}{c}{ PORTFOLIO } \\
\hline $\begin{array}{c}\text { Stock } \\
\text { Code }\end{array}$ & $\begin{array}{c}\text { Weight } \\
(\%)\end{array}$ & Return & Risk & Beta & $\begin{array}{c}\text { Return } \\
(\%)\end{array}$ & $\begin{array}{c}\text { Risk } \\
(\%)\end{array}$ & $\begin{array}{c}\text { Beta } \\
\text { Alpha } \\
(\%)\end{array}$ & $\begin{array}{c}\mathrm{R}^{2} \\
(\%)\end{array}$ & $\begin{array}{c}\text { Sharpe } \\
\text { Ratio }\end{array}$ & $\begin{array}{c}\text { Market } \\
\text { Risk }\end{array}$ & $\begin{array}{c}\text { Non-systematic } \\
\text { Risk }\end{array}$ \\
\hline AKSA & 20.3205 & 0.1076 & 20.521 & 0.7672 & 0.1073 & 14.943 & 0.8349 & 0.0706 & 66.6053 & 0.0553 & 12.196 & 0.8635 \\
ARCLK & 18.6189 & 0.0905 & 21.765 & 0.9664 & & & & & & & & \\
FROTO & 27.8862 & 0.1275 & 21.405 & 0.8140 & & & & & & & & \\
TAVHL & 19.6410 & 0.1174 & 22.104 & 0.7689 & & & & & & & & \\
TUPRS & 13.5334 & 0.0733 & 20.067 & 0.8944 & & & & & & & & \\
\hline
\end{tabular}

In Table 16, components of the portfolio of 5 stocks and the performance, risk and return outcomes of the portfolio are presented. The risk of the portfolio, which has $0.1073 \%$ income, is $1.4943 \%$. In terms of performance values, with Sharpe Ratio of 0.0553 and Alpha value of $0.0706 \%$, it gave positive results. 
Table 17. Portfolio components and results created by fuzzy TOPSIS 5

\begin{tabular}{ccccccccccccc}
\hline \multicolumn{3}{c}{ PORTFOLIO COMPONENTS } & \multicolumn{1}{c}{ PORTFOLIO } \\
\hline $\begin{array}{c}\text { Stock } \\
\text { Code }\end{array}$ & $\begin{array}{c}\text { Weight } \\
(\%)\end{array}$ & Return & Risk & Beta & $\begin{array}{c}\text { Return } \\
(\%)\end{array}$ & $\begin{array}{c}\text { Risk } \\
(\%)\end{array}$ & $\begin{array}{c}\text { Beta } \\
\text { Alpha } \\
(\%)\end{array}$ & $\begin{array}{c}\mathrm{R}^{2} \\
(\%)\end{array}$ & $\begin{array}{c}\text { Sharpe } \\
\text { Ratio }\end{array}$ & $\begin{array}{c}\text { Market } \\
\text { Risk }\end{array}$ & $\begin{array}{c}\text { Non-systematic } \\
\text { Risk }\end{array}$ \\
\hline AKSA & 18.3545 & 0.1076 & 20.521 & 0.7672 & 0.1034 & 14.397 & 0.8187 & 0.0669 & 69.0139 & 0.0547 & 11.960 & 0.8014 \\
ARCLK & 16.8174 & 0.0905 & 21.765 & 0.9664 & & & & & & & & \\
FROTO & 25.1881 & 0.1275 & 21.405 & 0.8140 & & & & & & & & \\
TAVHL & 17.7407 & 0.1174 & 22.104 & 0.7689 & & & & & & & & \\
TTKOM & 9.6753 & 0.0669 & 17.595 & 0.6681 & & & & & & & & \\
TUPRS & 12.2240 & 0.0733 & 20.067 & 0.8944 & & & & & & & & \\
\hline
\end{tabular}

In Table 17, portfolio data based on 6 stocks formed according to the Fuzzy TOPSIS are presented. The risk of the portfolio, which has $0.1034 \%$ income, is $1.4397 \%$. Portfolio outcomes, which reveal efficient results in terms of performance values, suggest the method's applicability in the selection of optimal portfolio. Besides all these explanations, as can be seen in the portfolio components determined based on Markowitz Model, diversification effect is in parallel with its negative correlation with return and risk.

\subsubsection{Evaluation and Comparison of Portfolios}

Evaluations on different portfolio alternatives formed via Fuzzy TOPSIS Method will be done through comparing with the portfolios formed based on modern portfolio theory. However, first, mutual interaction between the stock certificates and the level of this interaction is shown by preparing the covariance matrix of the stock certificates that are essential to the diversification composed of stock recommendations. Covariance matrix for the relevant stocks is shown in Table 18 .

Table 18. Covariance matrix of stocks

\begin{tabular}{ccccccccccccccccccc}
\hline XUTUM & AEFES & AKSA & ARCLK BANVT ENKAI EREGL KOZAL FROTO MGROS & PETKM & \multicolumn{1}{l}{ SELEC TAVHL TKFEN TTKOM TUPRS } \\
\hline AEFES & 40.214 & 0.8859 & 11.648 & 0.9424 & 0.9643 & 0.7273 & 0.9666 & 0.8380 & 10.519 & 0.8724 & 0.7998 & 0.8825 & 0.9450 & 0.8584 & 10.310 \\
AKSA & 0.8859 & 42.111 & 16.768 & 15.262 & 13.634 & 15.044 & 14.781 & 10.372 & 18.337 & 15.172 & 13.493 & 13.584 & 17.572 & 11.365 & 14.281 \\
ARCLK & 11.648 & 16.768 & 47.373 & 17.263 & 16.749 & 17.220 & 19.913 & 11.613 & 17.913 & 15.947 & 12.431 & 18.026 & 20.085 & 14.860 & 18.658 \\
BANVT & 0.9424 & 15.262 & 17.263 & 49.565 & 11.952 & 15.440 & 16.152 & 13.255 & 19.167 & 15.123 & 12.913 & 15.039 & 16.688 & 10.753 & 14.045 \\
ENKAI & 0.9643 & 13.634 & 16.749 & 11.952 & 37.059 & 13.956 & 13.838 & 12.433 & 15.195 & 13.850 & 11.109 & 14.620 & 17.120 & 10.265 & 14.347 \\
EREGL & 0.7273 & 15.044 & 17.220 & 15.440 & 13.956 & 34.496 & 13.778 & 13.805 & 17.449 & 16.620 & 12.118 & 15.885 & 16.291 & 10.795 & 15.205 \\
FROTO & 0.9666 & 14.781 & 19.913 & 16.152 & 13.838 & 13.778 & 45.819 & 11.343 & 21.562 & 13.623 & 11.730 & 14.197 & 18.428 & 12.273 & 17.227 \\
KOZAL & 0.8380 & 10.372 & 11.613 & 13.255 & 12.433 & 13.805 & 11.343 & 68.717 & 14.347 & 11.119 & 10.596 & 12.165 & 11.780 & 10.512 & 14.072 \\
MGROS & 10.519 & 18.337 & 17.913 & 19.167 & 15.195 & 17.449 & 21.562 & 14.347 & 57.911 & 19.393 & 15.146 & 16.616 & 21.852 & 14.764 & 17.920 \\
PETKM & 0.8724 & 15.172 & 15.947 & 15.123 & 13.850 & 16.620 & 13.623 & 11.119 & 19.393 & 37.439 & 11.881 & 13.713 & 18.795 & 11.023 & 15.502 \\
SELEC & 0.7998 & 13.493 & 12.431 & 12.913 & 11.109 & 12.118 & 11.730 & 10.596 & 15.146 & 11.881 & 35.202 & 10.163 & 15.279 & 0.7856 & 12.696 \\
TAVHL & 0.8825 & 13.584 & 18.026 & 15.039 & 14.620 & 15.885 & 14.197 & 12.165 & 16.616 & 13.713 & 10.163 & 48.857 & 18.467 & 11.133 & 14.447 \\
TKFEN & 0.9450 & 17.572 & 20.085 & 16.688 & 17.120 & 16.291 & 18.428 & 11.780 & 21.852 & 18.795 & 15.279 & 18.467 & 42.729 & 14.710 & 19.164 \\
TTKOM & 0.8584 & 11.365 & 14.860 & 10.753 & 10.265 & 10.795 & 12.273 & 10.512 & 14.764 & 11.023 & 0.7856 & 11.133 & 14.710 & 30.957 & 14.812 \\
TUPRS & 10.310 & 14.281 & 18.658 & 14.045 & 14.347 & 15.205 & 17.227 & 14.072 & 17.920 & 15.502 & 12.696 & 14.447 & 19.164 & 14.812 & 40.268 \\
\hline
\end{tabular}

In Modern Portfolio Theory, investor's asset combinations with the lowest risk at different return levels are called effective portfolio. Each portfolio component above the active border shows either the components that provide risk minimization at a certain return level or provide return maximization at a certain risk level. In order to be able to comparatively evaluate the portfolio components formed based on the fuzzy TOPSIS method in terms of risk, return and performance trilogy, effective portfolio components with the same rate of return should be taken as basis. The active border curve that the efficient portfolio components of the stock shares formed according to the brokerage house's recommendations is based on is presented in Figure 3. 


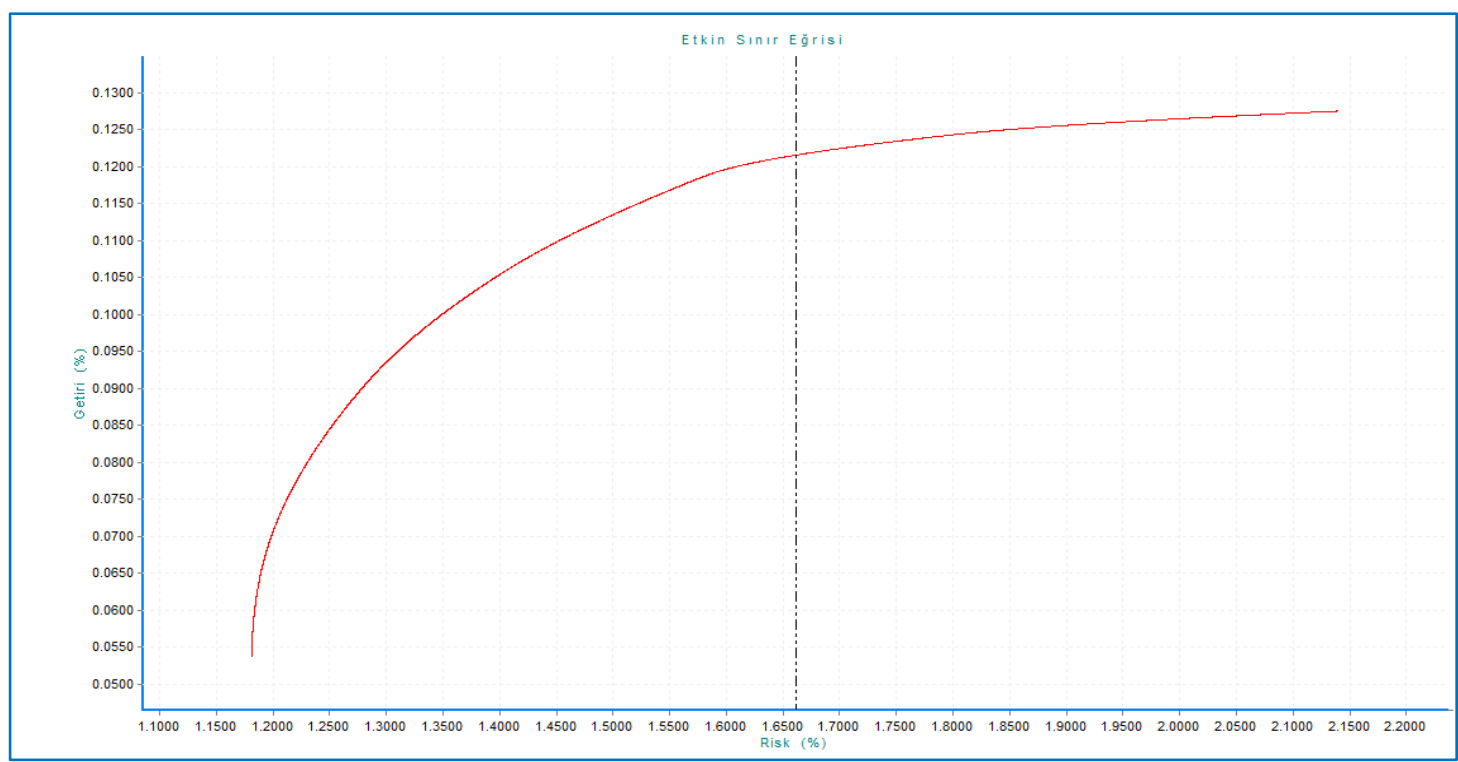

Figure 3. Effective boundary curve

Markowitz efficient portfolio components that show the target return level in portfolio components calculated based on Fuzzy TOPSIS Method and the risk, return, and performance calculations of these portfolio are calculated based on the formulae of equations 15-18 and are shown in Table 19-23.

Table 19. Portfolio components and results created by markowitz 1

\begin{tabular}{|c|c|c|c|c|c|c|c|}
\hline \multicolumn{8}{|c|}{ PORTFOLIO COMPONENTS } \\
\hline & & Stock Code & & & & Weights $(\%)$ & \\
\hline & & FROTO & & & & 42.5375 & \\
\hline & & TAVHL & & & & 30.8100 & \\
\hline & & AKSA & & & & 26.6526 & \\
\hline \multicolumn{8}{|c|}{ PORTFOLIO } \\
\hline Return \% & Risk \% & Beta & Alpha\% & $\mathrm{R}^{2} \%$ & Sharpe Ratio & Market Risk & Non-systematic Risk \\
\hline 0.1073 & 14.943 & 0.8349 & 0.0706 & 66.6053 & 0.5553 & 12.196 & 0.8635 \\
\hline
\end{tabular}

The results of the portfolio component shown in Table 12 among the portfolio components determined by the Fuzzy TOPSIS Method are acceptable in terms of risk, return, performance and other results. However, the same target return in terms of the relevant portfolio can be achieved via the efficient portfolio component in Table 19 based on the Markowitz model. When both portfolio components are compared, it can be seen that the portfolio component based on Markowitz model is more advantageous in terms of risk. However, in terms of Alpha coefficient, the return based on the risk taken seems satisfactory. In terms of market risk, the outlook that seems in favor of the Markowitz model can be interpreted as the effect of diversification based on the surplus of portfolio components.

Table 20. Portfolio components and results created by markowitz 2

\begin{tabular}{|c|c|c|c|c|c|c|c|}
\hline \multicolumn{8}{|c|}{ PORTFOLIO COMPONENTS } \\
\hline & & Stock Code & & & & Weights $(\%)$ & \\
\hline & & FROTO & & & & 40.9968 & \\
\hline & & TAVHL & & & & 30.5623 & \\
\hline & & AKSA & & & & 27.7723 & \\
\hline & & EREGL & & & & 0.6686 & \\
\hline \multicolumn{8}{|c|}{ PORTFOLIO } \\
\hline Return $\%$ & Risk \% & Beta & Alpha\% & $\mathrm{R}^{2} \%$ & Market Risk & Sharpe Ratio & Non-systematic Risk \\
\hline 0.1186 & 1.5792 & 0.7871 & 0.0879 & 53.0117 & 1.1498 & 0.0751 & 1.0825 \\
\hline
\end{tabular}

The results of the portfolio component shown in Table 12 among the portfolio components determined by the 
Fuzzy TOPSIS method are acceptable in terms of risk, return, performance and other results. However, the same target return in terms of the relevant portfolio can be achieved via the efficient portfolio component in Table 20 based on the Markowitz model. When both portfolio components are compared, the similarity between the portfolio components and the similarity between these components in terms of their significance in the portfolio are striking. Although the diversification intensity is higher in Markowitz model, the portfolio components composed of the same stock certificates reveals that the Fuzzy TOPSIS method is more applicable. However, it can be said that the portfolio results are in favor of Markowitz model.

Table 21. Portfolio components and results created by markowitz 3

\begin{tabular}{|c|c|c|c|c|c|c|c|}
\hline \multicolumn{8}{|c|}{ PORTFOLIO COMPONENTS } \\
\hline & & Stock Code & & & & Weights ( & \\
\hline & & FROTO & & & & & \\
\hline & & TAVHL & & & & & \\
\hline & & AKSA & & & & & \\
\hline & & TTKOM & & & & & \\
\hline & & EREGL & & & & & \\
\hline & & PETKM & & & & & \\
\hline \multicolumn{8}{|c|}{ PORTFOLIO } \\
\hline Return \% & Risk \% & Beta & Alpha\% & $\mathrm{R}^{2} \%$ & Market Risk & Sharpe Ratio & Non-systematic Risk \\
\hline 0.1126 & 1.4874 & 0.7818 & 0.0821 & 58.9513 & 1.1420 & 0.0757 & 0.9530 \\
\hline
\end{tabular}

Among the portfolio components determined according to the Fuzzy TOPSIS Method, the results of the portfolio component in Table 12 seem acceptable in terms of risk, return, performance and other results. According to Markowitz model, the same target return can be achieved via the efficient portfolio component in Table 21 . When both portfolio components are compared; high explanatory power of the determination coefficient of the fuzzy TOPSIS portfolio component is striking. Although it points to an evaluation in favor of the method, the low portfolio risk based on the intensity of diversification in the Markowitz model portfolio component may be considered sufficient since the aim of the study is to reveal that the fuzzy TOPSIS method can be used rather than to compare the methods.

Table 22. Portfolio components and results created by markowitz 4

\begin{tabular}{|c|c|c|c|c|c|c|c|}
\hline \multicolumn{8}{|c|}{ PORTFOLIO COMPONENTS } \\
\hline & & Stock Code & & & & Weigh & \\
\hline & & FROTO & & & & & 5054 \\
\hline & & TAVHL & & & & & 246 \\
\hline & & AKSA & & & & & 936 \\
\hline & & TTKOM & & & & & 2673 \\
\hline & & EREGL & & & & & 7738 \\
\hline & & PETKM & & & & & 353 \\
\hline \multicolumn{8}{|c|}{ PORTFOLIO } \\
\hline Return \% & Risk \% & Beta & Alpha\% & $\mathrm{R}^{2} \%$ & Market Risk & Sharpe Ratio & Non-systematic Risk \\
\hline 0.1073 & 1.4202 & 0.7760 & 0.0770 & 63.6934 & 1.1335 & 0.0755 & 0.8558 \\
\hline
\end{tabular}

According to Fuzzy TOPSIS Method, the results of the portfolio component shown in Table 12 are acceptable in terms of risk, return, performance and other results. The target return level of $0.1073 \%$ can be achieved in Markowitz model via the efficient portfolio component in Table 22. While lower risk level of the Markowitz model based on diversification is observed in the comparison, higher explanatory power in terms of determination coefficient is in favor of fuzzy TOPSIS method portfolio component. 
Table 23. Portfolio components and results created by markowitz 5

\begin{tabular}{|c|c|c|c|c|c|c|c|}
\hline \multicolumn{8}{|c|}{ PORTFOLIO COMPONENTS } \\
\hline & & Stock Code & & & & Weights ( & \\
\hline & & FROTO & & & & \multicolumn{2}{|c|}{26.3965} \\
\hline & & TAVHL & & & & \multicolumn{2}{|c|}{20.8580} \\
\hline & & AKSA & & & & \multicolumn{2}{|c|}{20.4593} \\
\hline & & TTKOM & & & & \multicolumn{2}{|c|}{14.1244} \\
\hline & & EREGL & & & & \multicolumn{2}{|c|}{9.2394} \\
\hline & & PETKM & & & & \multicolumn{2}{|c|}{7.5170} \\
\hline & & AEFES & & & & \multicolumn{2}{|c|}{1.4053} \\
\hline \multicolumn{8}{|c|}{ PORTFOLIO } \\
\hline Return \% & Risk \% & Beta & Alpha\% & $\mathrm{R}^{2} \%$ & Market Risk & Sharpe Ratio & Non-systematic Risk \\
\hline 0.1034 & 1.3799 & 0.7690 & 0.0733 & 66.2732 & 1.1234 & 0.0749 & 0.8014 \\
\hline
\end{tabular}

Among the portfolio components determined based on the Fuzzy TOPSIS method, the return level in the portfolio component shown in Table 12 can be achieved through the efficient portfolio shown in Table 23 based on the Markowitz Model. Fuzzy TOPSIS portfolio component is acceptable in terms of its risk, return, performance and other results, and has a higher explanatory power than Markowitz in terms of determination coefficient. Diversification intensity is more intense in Markowitz portfolio component, and because of that, it carries a relatively lower risk. However, it is in favor of Fuzzy TOPSIS method, which has a higher determination coefficient in terms of the power to obtain the target return.

\section{Overall Evaluation and Conclusion}

As a result of the findings of this study which investigates the applicability of Fuzzy TOPSIS Method as an alternative method in optimal portfolio selection, it was found that portfolio components obtained according to the method are applicable based on their risk, return, performance and other results. Since the relatively lower risk at the same return level provided by the active portfolios determined according to Markowitz's Modern Portfolio Theory emphasizes the superiority of the method, its goal is not to compare the methods when deciding the optimal portfolio selection, and thus, the applicability of fuzzy TOPSIS method will not be altered. However, since fuzzy TOPSIS method is based on the linguistic evaluation of the decision makers, it is open for improvement based on the accumulation of knowledge of the decision makers about the decision criteria. It can also be said that the method requires improvement. This deficiency in the fuzzy TOPSIS method can be seen more clearly when the effect of the diversification in the portfolio components and the relatively lower risk in the Markowitz method are taken into account. However, it can be said that, in all the portfolio components calculated according to the method, higher explanatory power obtained by the magnitude of the determination coefficient and with the improvement devised towards diversification, more positive results that can be achieved.

\section{References}

Aksoy, A., \& Tanrıven, C. (2007). Sermaye Piyasası Yatırım Araçları ve Analizi, 3.Baski. Ankara: Gazi Kitabevi.

Akyuz, G., \& Kilinc, E. (2016). Using Fuzzy TOPSIS Approach for Facility Location Selection: An Application in Medical Sector. Journal of Academic Social Science, 4(33), 590-608.

Alemi, M. A., \& Akram, R. (2013). Measuring the Leanness of Manufacturing Systems by Using Fuzzy TOPSIS: A Case Study of the 'Parizan Sanat' Company. South African Journal of Industrial Engineering, 24(3), 166-174.

Altas, I. H. (1999). Bulanık Mantık: Bulanıklık Kavramı. Enerji, Elektrik, Elektromekanik-3e, 62, 80-85.

Ardakani, S. S., Nejatian, M., Farhangnejad, M. A., \& Nejati, M. (2015). A Fuzzy Approach to Service Quality Diagnosis. Marketing Intelligence \& Planning, 33(1), 103-119. http://dx.doi.org/10.1108/MIP-02-2013-0035

Arslan, H. M., \& Yildiz, M. S. (2015). Application of Fuzzy TOPSIS Method on Location Selection of Educational Facilities: A Location Analysis in Duzce. The Journal of International Social Research, 8(36), 763-773. https://doi.org/10.17719/jisr.2015369541

Ashrafzadeh, M., Rafiei, F. K., Isfahani, N. M., \& Zare, Z. (2012). Application of Fuzzy TOPSIS Method for the Selection of Warehouse Location: A Case Study. Interdisciplinary Journal of Contemporary Research in Business, 3(9), 655-671. 
Awasthi, A., \& Chauhan, S. S. (2012). A Hybrid Approach Integrating Affinity Diagram, AHP and Fuzzy TOPSIS for Sustainable City Logistics Planning. Applied Mathematical Modelling, 36(2), 573-584. https://doi.org/10.1016/j.apm.2011.07.033

Bagheri, F., \& Tarokh, M. J. (2010). A Fuzzy Approach for Multi-Objective Supplier Selection. International Journal of Industrial Engineering \& Production Research, 21(1), 1-9.

Baskaya, Z., \& Ozturk, B. (2011). Evaluation of Salesperson Candidate's with Fuzzy TOPSIS. Business and Economics Research Journal, 2(2), 77-100.

Bottani, E., \& Rizzi A. (2006). A fuzzy TOPSIS Methodology to Support Outsourcing of Logistics Services. Supply Chain Management: An International Journal, 11(4), 294-308. https://doi.org/10.1108/13598540610671743

Buyukozkan, G., \& Cifci, G. (2012). A Novel Hybrid MCDM Approach Based on Fuzzy DEMATEL, Fuzzy ANP and Fuzzy TOPSIS to Evaluate Green Suppliers. Expert Systems with Applications, 39(3), 3000-3011. https://doi.org/10.1016/j.eswa.2011.08.162

Ceylan, A., \& Korkmaz, T. (1998). Borsada Uygulamalı Portföy Yönetimi. Bursa: Ekin Yayınları.

Chen, C. T. (2000). Extensions of the TOPSIS for Group Decision-Making under Fuzzy Environment. Fuzzy Sets and Systems, 114(1), 1-9. https://doi.org/10.1016/S0165-0114(97)00377-1

Chen, C. T. (2001). A Fuzzy Approach to Select The Location of The Distribution Center. Fuzzy Sets and Systems, 118(1), 65-73. https://doi.org/10.1016/S0165-0114(98)00459-X

Chen, C. T., Lin, C. T., \& Huang, S. F. (2006). A fuzzy approach for supplier evaluation and selection in supply chain management. Int. J. Production Economics, 102(2), 289-301. https://doi.org/10.1016/j.ijpe.2005.03.009

Chen, S. J., \& Hwang, C. L. (1992). Fuzzy Multiple Attribute Decisin Making Methods and Applicatons. Berlin Heidelberg: Springer-Verlag. https://doi.org/10.1007/978-3-642-46768-4

Chen, S. Y., \& Lu, C. C. (2015). Assessing the competitiveness of insurance corporations using fuzzy correlation analysis and improved fuzzy modified TOPSIS. Expert Systems, 32(3), 392-404. https://doi.org/10.1111/exsy.12099

Deng, H., Yeh, C. H., \& Willis, R. J. (2000). Inter-Company Comparison using Modified TOPSIS with Objective $\begin{array}{lllll}\text { Weights. Computers \& } \quad \text { Operations } & \text { Research, 27(10), }\end{array}$ https://doi.org/10.1016/S0305-0548(99)00069-6

Dundar, S., Ecer, F., \& Ozdemir, S. (2007). Fuzzy TOPSIS Yöntemi İle Sanal Mağazaların Web Sitelerinin Değerlendirilmesi. Ataturk University Journal of Economics and Administrative Sciences, 21(1), 287-305.

Ecer, F. (2006). Bulanık Ortamlarda Grup Kararı Vermeye Yardımcı Bir Yöntem: Fuzzy TOPSIS ve Bir Uygulama. Istanbul University Journal of The School of Business, 7(2), 77-96.

Ecer, F. (2007). A New Approach Towards Evaulation and Selection of Salesperson Candidates: Fuzzy TOPSIS. Anadolu University Journal of Social Sciences, 7(2), 187-204.

Ecer, F. (2007). Evaluation of Store Plant Locations in Fuzzy Environments: Fuzzy TOPSIS Method as a Decision-Making Tool. Hacettepe University the Journal of Faculty of Economics and Administrative Sciences, 25(1), 143-170.

Ecer, F., Vurur, N. S., \& Ozdemir, L. (2009). Assessing of Firms Using A Fuzzy Model and Optimal Portfolio Composing: An Application In Cement Industry. Mustafa Kemal University Journal of Social Sciences Institute, 6(11), 478-502.

Eleren, A., \& Ersoy, M. (2007). Evaluation of Marble Extraction Methods By Using Fuzzy TOPSIS Method. The Journal of the Chamber of Mining Engineers of Turkey, 46(3), 9-22.

Eleren, A., \& Yilmaz, C. (2011). Selection of Suppliers by Fuzzy TOPSIS Model; Sample Study From Turkey. International Journal of Business and Social Science, 2(22), 189-200.

Eraslan, E., \& Tansel, Y. (2011). A Multi-criteria Approach for Determination of Investment Regions: Turkish $\begin{array}{lllll}\text { case. Industrial Management \& Data Systems, } & 111(6), \quad 890-909 .\end{array}$ https://doi.org/10.1108/02635571111144964

Erginel, N., Cakmak, T., \& Senturk, S. (2010). Determining The Preference of GSM Operators In Turkey with Fuzzy TOPSIS After Mobile Number Portability System Application. Anadolu University Journal of 
Science and Technology-A Applied Sciences and Engineering, 11(2), 81-93.

Erkayman, B., Gundogar, E., Akkaya, G., \& Ipek, M. (2011). A Fuzzy TOPSIS Approach For Logistics Center Location Selection. Journal of Business Case Studies, 7(3), 49-55. https://doi.org/10.19030/jbcs.v7i3.4263

Gokdalay, M. H., \& Evren, G. (2009). Fuzzy multicriteria decision making approach for airport performance analysis. Itüdergisi/d Mühendislik, 8(6), 157-168.

Gul, D., \& Uludag, A. S. (2016). Determination of the Most Charismatic Leader Using Analytic Hierarchy Process and Fuzzy TOPSIS: An Application in Turkey. International Business Research, 9(7), 80-97. https://doi.org/10.5539/ibr.v9n7p80

Hsu, L.C., Ou, S. L., \& Ou, Y. C. (2015). A Comprehensive Performance Evaluation and Ranking Methodology Under A Sustainable Development Perspective. Journal of Business Economics and Management, 16(1), 74-92. https://doi.org/10.3846/16111699.2013.848228

Huang, J. H., \& Peng, K. H. (2012). Fuzzy Rasch Model in TOPSIS: A New Approach for Generating Fuzzy Numbers to Assess the Competitiveness of the Tourism Industries in Asian Countries. Tourism Management, 33(2), 456-465. https://doi.org/10.1016/j.tourman.2011.05.006

Kabra, G., \& Ramesh, A. (2015). Analyzing Drivers and Barriers of Coordination in Humanitarian Supply Chain Management under Fuzzy environment. Benchmarking: An International Journal, 22(4), 559-587. https://doi.org/10.1108/BIJ-05-2014-0041

Kahraman, C., Ates, N.Y., Cevik, S., Gulbay, M., \& Erdogan, S. A. (2007). Hierarchical Fuzzy TOPSIS Model for Selection among Logistics Information Technologies. Journal of Enterprise Information Management, 20(2), 143-168. https://doi.org/10.1108/17410390710725742

Kahraman, C., Suder, A., \& Cebi, S. (2013). Fuzzy Multi-criteria and Multi-experts Evaluation of Government Investments in Higher Education: the Case of Turkey. Technological and Economic Development of Economy, 19(4), 549-569. https://doi.org/10.3846/20294913.2013.837110

Karan, M. B. (2011). Yattrım Analizi ve Portföy Yönetimi, 3.Baski. Ankara: Gazi Kitabevi.

Kocel, T. (2005). İsletme Yonetimi, 10.Baskr. Istanbul: Arikan.

Konuralp, G. (2005). Sermaye Piyasaları\&Analizler Kuramlar ve Portföy Yönetimi, 2.Baski. Istanbul: Alfa.

Kucuk, O., \& Ecer, F. (2007). Assesing Suppliers Using Fuzzy TOPSIS and An Application in Erzurum. The International Journal of Economic and Social Research, 3(1-3), 45-65.

Madi, E. N., \& Tap, A. O. M. (2011). Fuzzy TOPSIS Method in the Selection of Investment Boards by Incorporating Operational. Proceedings of the World Congress on Engineering 2011, July 6-8, Vol I.

Mahdevari, S., Shahriar, K., \& Esfahanipour. (2014). Human health and safety risks management in under ground coalmines using fuzzy TOPSIS. Science of the Total Environment, 488-489, 85-99. https://doi.org/10.1016/j.scitotenv.2014.04.076

Mahdi, B., \& Hossein, B. (2008). Project Selection with Outsourcing View Using Fuzzy TOPSIS Linear Assignment Programming. Proceedings of the 2008 IEEE, 327-332. https://doi.org/10.1109/ICMIT.2008.4654385

Maity, S. R., \& Chakraborty, S. (2013). Grinding Wheel Abrasive Material Selection Using Fuzzy TOPSIS $\begin{array}{llll}\text { Method. Materials and Manufacturing } & \text { Processes, } & \text { 28(4), }\end{array}$ https://doi.org/10.1080/10426914.2012.700159

Mangir, F., \& Erdogan, S. (2011). Comparison of Economic Performance Among Six Countries in Global Financial Crisis: The Application of Fuzzy TOPSIS Method. Economics, Management, and Financial Markets, 6(2), 122-136.

Mokhtari, S. M., Alinejad-Rokny, H., \& Jalalifar, H. (2014). Selection of the best well control system bey using fuzzy multiple-attribute decision-making methods. Journal of Applied Statistics, 41(5), 1105-1121. https://doi.org/10.1080/02664763.2013.862218

Onut, S., \& Soner, S. (2008). Transshipment site selection using the AHP and TOPSIS approaches under fuzzy environment. Waste Management, 28, 1552-1559. https://doi.org/10.1016/j.wasman.2007.05.019

Ozcakar, N., \& Demir, H. (2011). Supplier Selection by Using The Fuzzy TOPSIS Method. Yönetim: İstanbul Üniversitesi Issletme İktisadi Enstitüsü Dergisi, 22(69), 25-44. 
Ozdemir, A. I., \& Secme, N. Y. (2009). İki Asamalı Stratejik Tedarikci Seciminin Bulanık TOPSIS Yontemi Ile Analizi. Afyon Kocatepe Univesity Journal of Economics and Administrative Sciences, 11(2), 79-112.

Ozturk, A., Ertugrul, I., \& Karakasoglu, N. (2008). Comparison of Fuzzy AHP and Fuzzy TOPSIS Methods in Transportation Firm Selection. Marmara University Journal of Economics and Administrative Sciences, 25(2), 785-824.

Paksoy, T., Pehlivan, N. Y., \& Kahraman, C. (2012). Organizational Strategy Development in Distribution Channel Management using Fuzzy AHP and Hierarchical Fuzzy TOPSIS. Expert Systems with Applications, 39(3), 2822-2841. https://doi.org/10.1016/j.eswa.2011.08.142

Prascevic, Z., \& Prascevic, N. (2013). One modification of Fuzzy TOPSIS method. Journal of Modelling in Management, 8(1), 81-102. https://doi.org/10.1108/17465661311311996

Reilly, F. K., \& Brovn, K. C. (2012). Investment Analysis\&Portfolio Management (10th ed.). South-Western Cengage Learning, Öice Presidend of Editorial Business, Boulevard, USA.

Ross, W. J. (2005). Corporate Finance (Vol. 1, 6th ed.). McGraw-Hill/Irwin, HcGravw-Hill Primis.

Salehi, M., \& Tavakkoli-Moghaddam, R. (2008). Project Selection by Using a Fuzzy TOPSIS Technique. International Scholarly and Scientific Research \& Innovation, 2(4), 375-380.

Sari, K. (2013). Selection of RFID Solutionprovider. Kybernetes, 42(3), 448-465. https://doi.org/10.1108/03684921311323680

Sedaghat, M. (2013). A Productivity Improvement Evaluation Model By Integrating AHP, TOPSIS and VIKOR Methods Under Fuzzy Environment (Case Study: Stateowned, Partially Private and Private Banks in Iran). Economic Computation \& Economic Cybernetics Studies \& Research, 47(1), 235-258.

Shahanaghi, K., \& Yazdian, S. A. (2009). Vendor Selection Using a New Fuzzy Group TOPSIS Approach. Journal of Uncertain Systems, 3(3), 221-231.

Sharpe, W. F. (1966). "Mutual Fund Performance", The Journal of Business, 39(1), 119-138 https://doi.org/10.1086/294846

Solimanpur, M., Mansourfar, G., \& Ghayour, F. (2015). Optimum Portfolio Selection Using a Hybrid Genetic Algorithm and Analytic Hierarchy Process. Studies in Economics and Finance, 32(3), 379-394. https://doi.org/10.1108/SEF-08-2012-0085

Sun, C. C., \& Lin, G. T. R. (2009). Using fuzzy TOPSIS Method for Evaluating the Competitive Advantages of Shopping websites. Expert Systems with Applications, 36, 11764-11771. https://doi.org/10.1016/j.eswa.2009.04.017

Tan, Y., Shen, L., Langston, C., \& Liu, Y. (2010). Construction Project Selection Using Fuzzy TOPSIS Approach. Journal of Modelling in Management, 5(3), 302-315. https://doi.org/10.1108/17465661011092669

Tirmikcioglu, C. N. (2010). Fuzzy TOPSIS Method for Facility Location Selection and An Application in Banking Sector. Karamanoglu Mehmet Bey University Journal of Social and Economic Research, 12(18), $37-45$.

Tsao, C. T. (2003). Evaluating Investment Values of Stocks Using A Fuzzy TOPSIS Approach. Journal of Information and Optimization Sciences, 24(2), 373-396. https://doi.org/10.1080/02522667.2003.10699573

Ulgen, H., \& Mirze, S. K. (2010). İsletmelerde Stratejik Yönetim. İstanbul: Beta Basım Yayın.

Uludag, A. S., \& Deveci, M. (2013b). Using The Multi Criteria Decision Making Methods in Facility Location Selection Problems and An Application. Abant Izzet Baysal University Journal of Social Sciences, 13(1), 257-288.

Uludag, A. S., Deveci, M. (2013a). Supplier Selection using the Fuzzy VIKOR and Fuzzy TOPSIS Methods and an Application. European Journal of Scientific Research, 98(2), 240-258.

Uysal, F., \& Tosun, O. (2012). Fuzzy TOPSIS-Based Computerized Maintenance Management System Selection. $\begin{array}{llll}\text { Journal of Manufacturing Technology } & \text { Management, 23(2), 228. }\end{array}$ https://doi.org/10.1108/17410381211202205

Vatansdever, K. (2013). Use of Fuzzy TOPSIS Method in Supplier Selection Decision and an Application. Anadolu University Journal of Social Sciences, 13(3), 155-168.

Vural, M. (2002). DüşünceTarihinde Mantık: Aristoteles Mantığından Bulanık Mantığa. Kutadgubilig, 2, 
179-192.

Website: http://www.tdkterim.gov.tr/bts/

Yayla, A. Y., Yildiz, A., \& Ozbek, A. (2012). Fuzzy TOPSIS Method in Supplier Selection and application in the Garment Industry. FIBRES \& TEXTILES in Eastern Europe, 4(93), 20-23.

Yildiz, A., \& Yildiz, D. (2014). Enterprice Resource Planning (ERP) Software Selection Process with Fuzzy TOPSIS Method. Business and Economics Research Journal, 5(1), 87-106.

Yong, D. (2006). Plant location selection based on fuzzy TOPSIS. Int.J.Adv.MAnuf.Technol., 28, 839-844. https://doi.org/10.1007/s00170-004-2436-5

Yoruk, N. (2000). Finansal Varlik Fiyatlama Modelleri ve Arbitraj Fiyatlama Modelinin IMKB'de Test Edilmesi. Istanbul: Istanbul Menkul Kiymetler Borsası.

\section{Copyrights}

Copyright for this article is retained by the author(s), with first publication rights granted to the journal.

This is an open-access article distributed under the terms and conditions of the Creative Commons Attribution license (http://creativecommons.org/licenses/by/4.0/). 